\title{
New species and new records of freshwater Chaetonotida (Gastrotricha) from Sweden
}

\author{
TOBIAS KÅNNEBY \\ Department of Invertebrate Zoology, Swedish Museum of Natural History, Box 50007, SE-104 05 Stockholm, Sweden. \\ E-mail: tobias.kanneby@nrm.se
}

\begin{abstract}
Gastrotricha is a small phylum of acoelomatic aquatic invertebrates common in both marine and freshwater environments. The freshwater gastrotrich fauna of Sweden is poorly known and so far only 20 species have been reported. In this study two species, Heterolepidoderma joermungandri n. sp. and $H$. trapezoidum $\mathbf{n}$. sp., are described as new to science. Moreover, 9 species are presented as new to the Swedish fauna. Additional taxonomic information is also given for 4 species previously reported from the country. In total 7 genera of two families, Chaetonotidae and Dasydytidae, are presented and the number of reported freshwater gastrotrichs from the country is increased to 31 .
\end{abstract}

Key words: Chaetonotidae, Dasydytidae, Freshwater fauna, taxonomy

\section{Introduction}

Gastrotricha is a small phylum of acoelomate metazoans. They have been reported from all continents and at present about 765 nominal species are known. Gastrotrichs are among the smallest metazoans and some species can be as small as $70 \mu \mathrm{m}$ in total body size. However, most freshwater species are larger and marine species can reach lengths up to 3.5 millimeters (Todaro \& Hummon in Artois et al. 2011). The group is widely distributed and can be found in all aquatic environments. In the sea gastrotrichs can rank third in abundance after nematodes and harpacticoid copepods and in freshwater habitats they are among the top five most common taxa encountered (Balsamo \& Todaro 2002). In marine habitats most species live interstitially, in fine to medium grained clean sand, where they constitute an important part of the meiofauna (Hummon 1982; Balsamo \& Todaro 2002). Freshwater species are mostly epibenthic or epiphytic but can also live interstitially. Certain genera (e. g. Haltidytes Remane, 1936 and Stylochaeta Hlava, 1904) have adapted to a semi-planktonic lifestyle (Schwank 1990).

Gastrotricha is divided into two orders, Macrodasyida Remane, 1925 which is almost exclusively marine and Chaetonotida Remane, 1925, with both marine and freshwater representatives. Macrodasyidans are vermiform and possess anterior, posterior and often lateral and dorsal adhesive tubes. Chaetonotidans are, with very few exceptions, tenpin-shaped and usually have only two posterior adhesive tubes forming a bifurcated caudal end called the furca. Most species of freshwater Chaetonotida belong to the family Chaetonotidae Gosse, 1864, but the semiplanktonic family Dasydytidae is also well represented (Schwank 1990).

Classification of Gastrotricha is mainly based on morphology and ultrastructure. Morphometry of the body and in particular of some structures, such as the furca and the pharynx are important characters for species identification as well as distribution and shape of scales and spines. The drawback of these characters is that their range in rarely recorded species is virtually unknown. This is problematic when knowledge on intraspecific variability increases and overlaps in characters encompass species boundaries.

The Swedish gastrotrich fauna is poorly known compared to other well investigated countries in the same temperate region. In Poland 98 species have been recorded and from Germany around 90 species are known (Balsamo et al. 2008). A couple of years ago only 7 freshwater species, all belonging to Chaetonotidae, had been reported from Sweden (see Hofsten 1923; Schwank 1990). Kånneby et al. (2009) described the new species Ichthydium 
skandicum Kånneby, Todaro and Jondelius, 2009 and gave additional data on I. diacanthum Balsamo and Todaro, 1995, I. squamigerum Balsamo and Fregni, 1995 and I. tanytrichum Balsamo, 1982, as well as on the associated gastrotrich fauna, increasing the number of known freshwater species from Sweden to 20. Most Swedish species have so far been recorded from stagnant waters with Sphagnum spp. and Lemna spp.

The purpose of this study is to increase the knowledge of gastrotrich biodiversity in Sweden. Some species reported in this paper have already been found in Sweden (see Hofsten 1923; Kånneby et al. 2009) but were not thoroughly studied. Species of the genus Chaetonotus Ehrenberg, 1830 are not treated here and will be the subject of a forthcoming publication.

\title{
Material and methods
}

Gastrotrichs were collected from 2007 to 2010 from different habitats in Sweden; ranging from Skåne in the south to Lapland in the north (Figure 1). Collection was done with a plankton net with a mesh size of $25 \mu \mathrm{m}$ or simply by collecting mosses, other vegetation and benthic material by hand. Samples were taken back to the laboratory and kept in aerated aquaria. Subsequently subsamples were taken from the aquaria and treated with $1 \% \mathrm{MgCl}_{2}$-solution to anaesthetize the animals. Individual gastrotrichs were extracted with a micropipette and studied alive. Pictures and documentation were made with a Nikon Eclipse 80i DIC microscope equipped with a Nikon Digital Sight DSFi1 digital camera. The description of species in this paper follows the convention of Hummon et al. (1992) where the position of certain morphological characters are given in percentage units $(U)$ of total body length measured from anterior to posterior (distal end of the furca). In species descriptions columns refer to scale rows parallel to the longitudinal body axis while scale rows refer to the rows of scales perpendicular to the longitudinal body axis.

Abbreviations: AL, Adhesive tube Length; CL, Caudal appendages Length; DC, \# Dorsal scale Columns; DR, \# Dorsal scale Rows; DSL, Dorsal Spine Length; FL, Furca Length; MD, Mouth Diameter; NA, Not Available; PhL, Pharynx Length; PL, scale Peduncle Length; SCA, number of Segments on Caudal Appendages; SG1-4, Spine Group 1-4; TL, Total Length; TNC, Total Number of scale Columns; TS, Trunk Scale length x width; TSp, \# Trunk Spines; VB, \# Ventral Bars below pharynx; VC, \# Ventral scale Columns; VR, \# Ventral scale Rows; VSL, Ventral Spine Length; VTS, Ventral Terminal Scales length $\mathrm{x}$ width.

\section{Results}

In total 15 species from 7 genera of 2 families are reported in this paper. Heterolepidoderma joermungandri $\mathbf{n}$. $\mathbf{s p .}$ and $H$. trapezoidum n. sp. are new to science. Aspidiophorus oculifer Kisielewski, 1981, A. ophiodermus Balsamo, 1982, Haltidytes crassus Greuter, 1917, Heterolepidoderma macrops Kisielewski, 1981, H. ocellatum (Metschnikoff, 1865), Lepidochaetus zelinkai (Grünspan, 1908), Lepidodermella minor minor (Remane, 1936), Polymerurus nodicaudus (Voigt, 1901) and Stylocheata scirtetica Brunson, 1950 are all new to the Swedish fauna. Moreover, additional information is given for A. squamulosus (Roszczak, 1936), A. tetrachaetus Kisielewski, 1986, L. squamata (Dujardin, 1841) and P. rhomboides (Stokes, 1887), all of which have been previously reported from Sweden. A list of all species reported from Sweden is presented in table 1.

\section{Taxonomy}

Order Chaetonotida Remane, 1925 [Rao \& Clausen, 1970]

\author{
Suborder Paucitubulatina d'Hondt, 1971
}

Family Chaetonotidae Gosse, 1864 (sensu Leasi \& Todaro, 2008)

Subfamily Chaetonotinae Kisielewski, 1991 


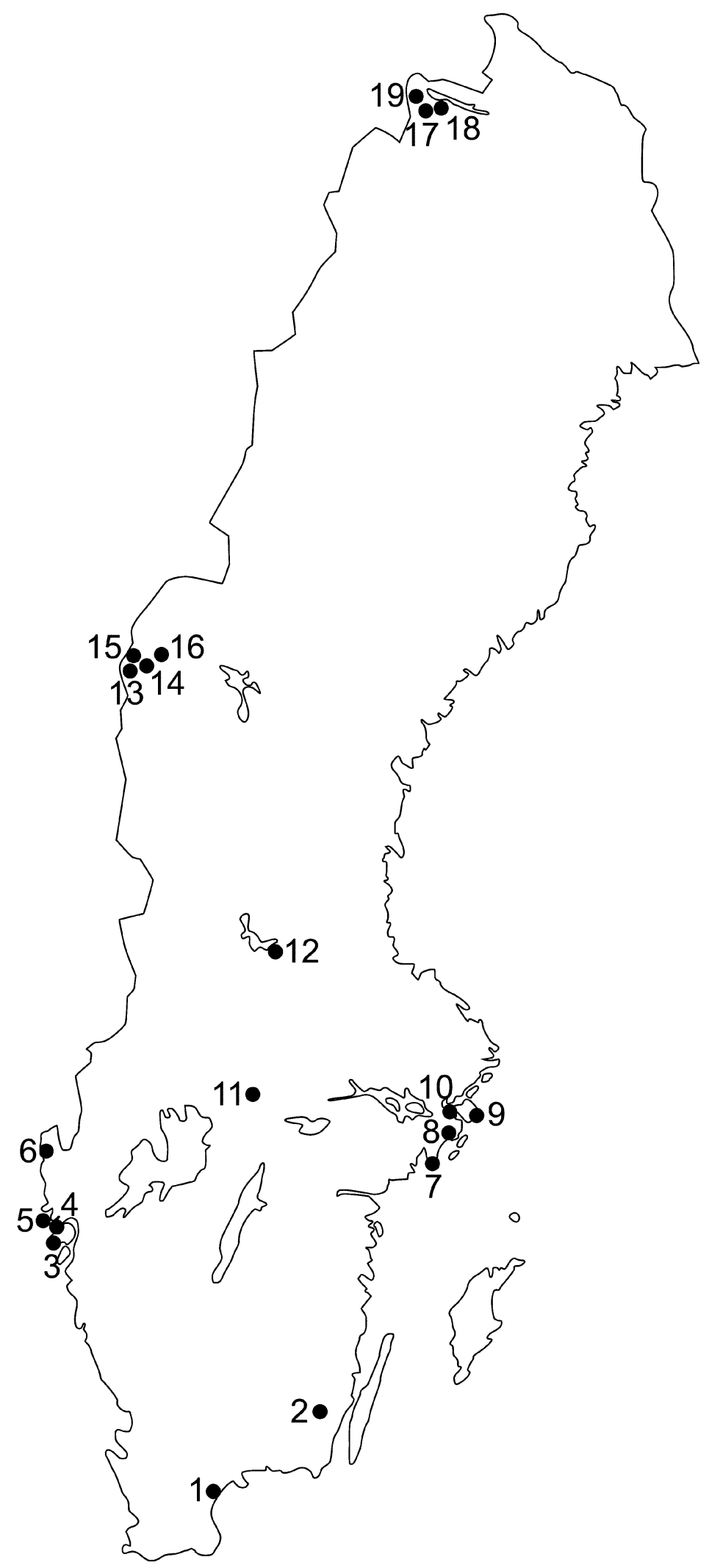

FIGURE 1. Map of Sweden showing the localities sampled in this study and by Kånneby et al. (2009). 1) Åhus, Skåne; 2) Nybro, Småland; 3) Islandsberg, Bohuslän; 4) Fiskebäckskil, Bohuslän; 5) Hållö and Skarvesäter, Bohuslän; 6) Saltö, Bohuslän; 7) Askö, Södermanland; 8) Lower Lake Rudan, Södermanland; 9) Runmarö, Stockholm archipelago; 10) Bergianska trädgården, Stockholm; 11) Lake Trösvattnet, Västmanland; 12) Lake Siljan, Dalarna; 13) Mount Snasahögarna, Jämtland; 14) Lake Ånnsjön, Jämtland; 15) Storlien W and Storlien E, Jämtland; 16) Highway E14 between Åre and Storlien, Jämtland; 17) Mount Njulla, Lapland; 18) Torneträsk and Abisko, Lapland; 19) Björkliden, Sphagnum spp. bogs and ditches at highway E10, Lapland. 
TABLE 1. Freshwater gastrotrich records from Sweden. The reference to species descriptions and references to the Swedish records are provided. The localities presented in Figure 1 are also listed for each species.

\begin{tabular}{|c|c|c|c|}
\hline Species & Reference to species description & $\begin{array}{l}\text { Reference to Swedish } \\
\text { records }\end{array}$ & $\begin{array}{l}\text { Distribution } \\
\text { (refer to Figure 1) }\end{array}$ \\
\hline \multicolumn{4}{|l|}{ Family Chaetonotidae } \\
\hline Aspidiophorus oculifer & Kisielewski, 1981 p. 84-86, Fig. 12 & This study & 18 \\
\hline Aspidiophorus ophiodermus & $\begin{array}{l}\text { Balsamo, } 1982 \text { p. } 294-295 \\
\text { Fig. 3, 4C, D }\end{array}$ & This study & 4,8 \\
\hline Aspidiophorus squamulosus & $\begin{array}{l}\text { (Roszczak, } 1936) \text { p. } 109 . \\
\text { Roszczak, } 1968 \text { p. } 66-68 \text {, Fig. } 42\end{array}$ & $\begin{array}{l}\text { Fauna Europaea; This } \\
\text { study }\end{array}$ & 1 \\
\hline Aspidiophorus tetrachaetus & Kisielewski, 1986 p. 141-143, Fig. 2 & $\begin{array}{l}\text { Kånneby et al. (2009); } \\
\text { This study }\end{array}$ & 4,14 \\
\hline Chaetonotus armatus & Kisielewski, 1981 p. 46-49, Fig. 5 & Kånneby et al. (2009) & 14 \\
\hline Chaetonotus benacensis & Balsamo \& Fregni, 1995 Fig. 3, 7A & Kånneby et al. (2009) & 12 \\
\hline Chaetonotus chuni & $\begin{array}{l}\text { Voigt, } 1901 \text { p. } 37-38 . \\
\text { Voigt, } 1904 \text { p. } 143-145 \text {, Fig. } 48,52\end{array}$ & Schwank (1990) & $?$ \\
\hline Chaetonotus heideri & Brehm, 1917 p. $315-316$ & Kånneby et al. (2009) & 14 \\
\hline Chaetonotus hystrix & Metschnikoff, 1865 p. 451 , Fig. 7 & Kånneby et al. (2009) & 12 \\
\hline Chaetonotus longispinosus & Stokes, 1887 p. 565 , Fig. $8-10$ & Schwank (1990) & $?$ \\
\hline Chaetonotus mutinensis & Balsamo, 1978 p. 114-118, Fig. 6 & Kånneby et al. (2009) & 10 \\
\hline Chaetonotus macrochaetus & Zelinka, 1889 p. $335-337$, Fig. 7-10 & Hofsten (1923) & Jämtland \\
\hline Chaetonotus maximus & (Ehrenberg, 1831) p. 153, Fig. 6 & Hofsten (1923) & Jämtland \\
\hline Chaetonotus oculifer & Kisielewski, 1981 p. $38-41$, Fig. 2 & Kånneby et al. (2009) & 16 \\
\hline Chaetonotus polyspinosus & Greuter, 1917 p. 50-52, Fig. 3 & Kånneby et al. (2009) & 14 \\
\hline Chaetonotus schultzei & Metschnikoff, 1865 p. 451 & Schwank (1990) & $?$ \\
\hline Heterolepidoderma joermungandri $\mathbf{n}$. sp. & This study & This study & 5 \\
\hline Heterolepidoderma macrops & Kisielewski, 1981 p. 71-73, Fig. 9 & This study & $5,18,19$ \\
\hline Heterolepidoderma ocellatum & (Metschnikoff, 1865) p. 451, Fig. 1 & This study & $3,4,6,7$ \\
\hline Heterolepidoderma trapezoidum $\mathbf{n} . \mathbf{s p .}$ & This study & This study & 13 \\
\hline Ichthydium diacanthum & $\begin{array}{l}\text { Balsamo \& Todaro, } 1995 \text { p. } 18-19 \text {, } \\
\text { Fig. } 9\end{array}$ & Kånneby et al. (2009) & 16 \\
\hline Ichthydium skandicum & Kånneby et al., 2009 p. 27-30, Fig. 1, 2 & Kånneby et al. (2009) & 16 \\
\hline Ichthydium squamigerum & $\begin{array}{l}\text { Balsamo \& Fregni, } 1995 \text { p. 171-172, } \\
\text { Fig. 6, 7C }\end{array}$ & Kånneby et al. (2009) & $10,11,12$ \\
\hline Ichthydium tanytrichum & $\begin{array}{l}\text { Balsamo, } 1982 \text { p. 292-294, Fig. 2, 4B, } \\
6\end{array}$ & Kånneby et al. (2009) & 14 \\
\hline Lepidochaetus zelinkai & $\begin{array}{l}\text { (Grünspan, 1908) p. 226-228, Plate } 18 \text {, } \\
\text { Fig. } 1\end{array}$ & This study & $\begin{array}{l}4,5,7,9,13,18 \\
19\end{array}$ \\
\hline Lepidodermella minor minor & $\begin{array}{l}\text { Remane, } 1936 \text { p. } 71,194 \text {. Fig. } 66 \text { A, B. } \\
\text { Kisielewski, } 1981 \text { p. } 78-79\end{array}$ & This study & 4 \\
\hline Lepidodermella squamata & $\begin{array}{l}\text { (Dujardin, 1841) p. 569, Plate 18, Fig. } \\
7-8\end{array}$ & $\begin{array}{l}\text { Hofsten, 1923; This } \\
\text { study }\end{array}$ & $\begin{array}{l}1,2,4,5,11,15 \\
17,18,19\end{array}$ \\
\hline Polymerurus nodicaudus & $\begin{array}{l}\text { (Voigt, 1901) p. } 193-194 . \\
\text { Voigt, } 1904 \text { p. } 134-137 \text {, Fig. } 42 \text { A-D }\end{array}$ & This study & 8,10 \\
\hline Polymerurus rhomboides & (Stokes, 1887) p. 561-562, Fig. 31-35 & $\begin{array}{l}\text { Kånneby et al. (2009); } \\
\text { This study }\end{array}$ & 11 \\
\hline \multicolumn{4}{|l|}{ Family Dasydytidae } \\
\hline Haltidytes crassus & (Greuter, 1917) p. 67-68, Fig. 16 & This study & 2 \\
\hline Stylochaeta scirtetica & Brunson, 1950 p. 336-338. Fig. 7, 8, 31 & This study & 2 \\
\hline
\end{tabular}




\section{Genus Aspidiophorus (Voigt, 1903)}

\section{Aspidiophorus oculifer Kisielewski, 1981}

(Figure 2)

Localities. A small pond close to lake Torneträsk at Abisko Scientific Research Station, Abisko, Lapland (N $68^{\circ}$ 21' 19'; E 18 49' 21').

Material. 1 specimen. TL, $120 \mu \mathrm{m}$; FL, $15 \mu \mathrm{m}$; AL, $6 \mu \mathrm{m}$; PhL, $30 \mu \mathrm{m}$; MD, $4 \mu \mathrm{m}$; DC, 19-20; DR, 40-42; VC, 9-10; TS, 3-4 x $3 \mu \mathrm{m}$; VTS, 10 x $4 \mu \mathrm{m}$; PL, 0.5-1 $\mu \mathrm{m}$.

A small sized and rather stout species with five-lobed head and a pair of ocellar granules. Hypostomium weakly developed. Adhesive tubes short, stocky and thick, ending in a notch. Anterior sensory bristles apparently absent, posterior sensory bristles anchored by double keeled scales. Dorsal scales are rhomboidal with rounded edges and increase in size towards the posterior end. Ventral interciliary field with a pair of spined terminal scales and 9-10 columns of keels; scales apparently not developed. Ventral ciliation in two longitudinal bands not merging on the head, however a short longitudinal band of ciliary rows is present behind the mouth. Pharynx slightly swollen at both ends. The Swedish specimen was in parthenogenetic phase and agrees well with literature data.

Previously recorded from Germany (Schwank 1990), Italy (Balsamo 1990), Poland (Kisielewski 1998), Russia (Tretjakova 1991) and Brazil (Kisielewski 1991).
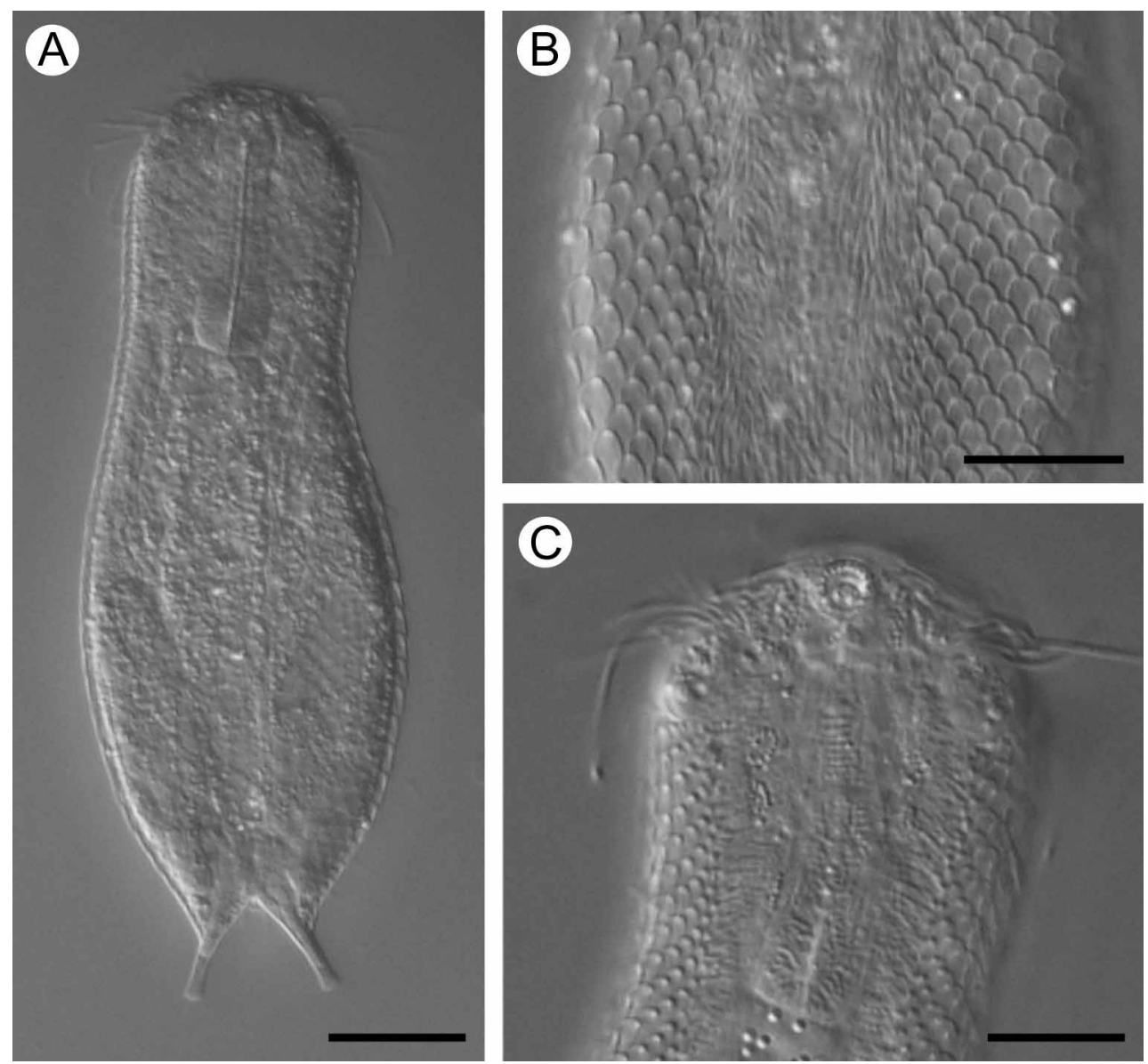

FIGURE 2. Aspidiophorus oculifer. A) Habitus. B) Ventral view, showing ventrolateral scales, ciliation and interciliary area. C) Ventral view showing shape of pharynx and mouth. Scale bars: A, $20 \mu \mathrm{m}$; B and C, $10 \mu \mathrm{m}$.

\section{Aspidiophorus cf. oculifer}

Localities. Sphagnum spp. Bog at Highway E10, Lapland (N 68 26'02"; E 18 15'01").

Material. 1 specimen. TL, $110 \mu \mathrm{m}$; FL, $12 \mu \mathrm{m}$; AL, $6 \mu \mathrm{m}$; PhL, 27-28 $\mu \mathrm{m}$; MD, 3-4 $\mu \mathrm{m}$; DC, 19-20; DR, 3638; VC, NA; TS, 3-4 x 3-4 $\mu \mathrm{m}$; VTS, 9-10 x NA $\mu \mathrm{m}$; PL, 0.5-1 $\mu \mathrm{m}$. 
The specimen of Aspidiophorus cf. oculifer agrees well with the description of A. oculifer above and data from the literature. However, the Swedish specimen disagrees with the description of A. oculifer in that it lacks a pair of ocellar granules. The lack of ocellar granules alone does not justify describing A. cf. oculifer as a new species. Ocellar granules have been reported to be either present or absent in different populations of the same species (e. g. Heterolepidoderma ocellatum) (Schwank 1990; Fregni et al. 1998).

\section{Aspidiophorus ophiodermus Balsamo, 1982}

(Figure 3)

Localities. Artificial ponds, Fiskebäckskil, Bohuslän (N 58 14' 39"; E $11^{\circ} 27^{\prime}$ 16”); Among Lemna sp., Lower Lake Rudan, Handen, Södermanland (N 59 09' 27'; E 18 07' 31").

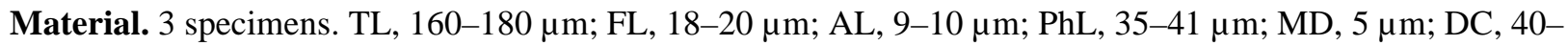
45; DR, 49-51; VC, 10; VTS, 8 x 4-5 $\mu \mathrm{m}$; PL, $0.5 \mu \mathrm{m}$.
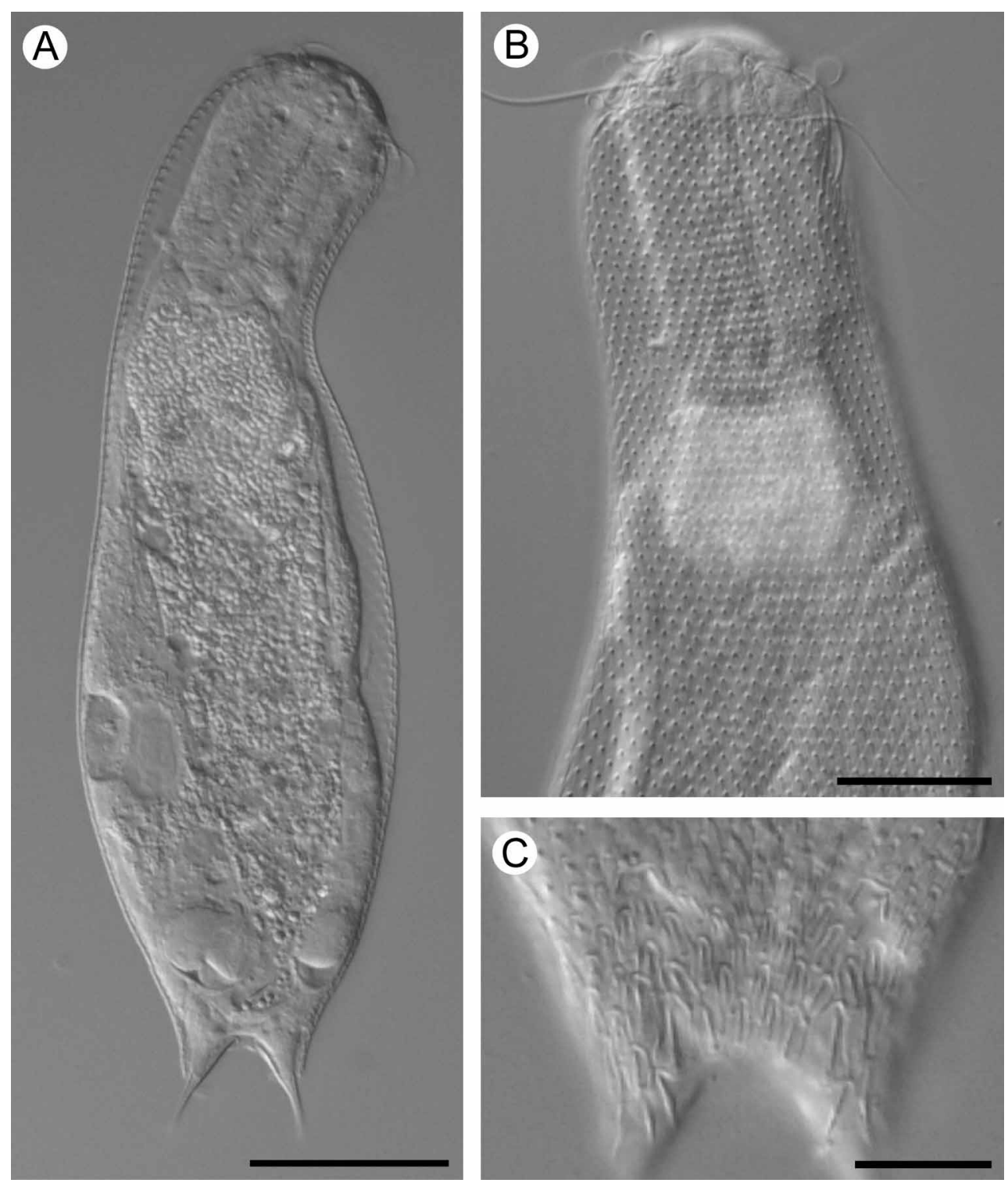

FIGURE 3. Aspidiophorus ophiodermus. A) Habitus. B) Dorsal view showing distribution of stalked scales. C) Dorsal view showing distribution and shape of scales of the furcal base. Scale bars: A, $50 \mu \mathrm{m} ; \mathrm{B}, 20 \mu \mathrm{m} ; \mathrm{C}, 10 \mu \mathrm{m}$.

A rather slim and elongated species with rounded to weakly three-lobed head. Cephalion well developed. One pair of cephalic ciliary tufts with one cilium considerably longer than the others. Two pairs of dorsal sensory bris- 
tles. The dorsal scales are longitudinal elliptical and keeled. The posteriormost scales are keeled but not pedunculated and larger than the others. Ventral interciliary field with a pair of large suboval keeled terminal scales and approximately 10 columns of keeled scales; their borders could not be seen. Ventral ciliation in two longitudinal bands that are further divided on the head, but not merging. Pharynx widens towards the pharyngeal intestinal junction. The Swedish specimens, all in parthenogentic phase with large eggs, fall within the ranges of literature data but are in general larger than most previously recorded specimens. The anteriormost part of the intestine has a granulated appearance, also recorded in Polish specimens (Kisielewski 1986).

Previously recorded from Great Britain (Martin 1990), Italy (Balsamo 1983), Poland (Kisielewski 1998), Russia (Tretjakova 1989) and Brazil (Kisielewski 1991).

\section{Aspidiophorus squamulosus (Roszczak, 1936)}

(Figure 4)

Localities. Gravel pit, Åhus, Skåne (N 55 55’ 43”; E 14 15’08”).

Material. 1 specimen. TL, $208 \mu \mathrm{m}$; FL, $21 \mu \mathrm{m}$; AL, 10-11 $\mu \mathrm{m}$; PhL, $50 \mu \mathrm{m}$; MD, $15 \mu \mathrm{m}$; DC, 28; DR, 43; $\mathrm{VC}, \sim 12$; TS, 4 x $4 \mu \mathrm{m}$; PL $0.5-1 \mu \mathrm{m}$.
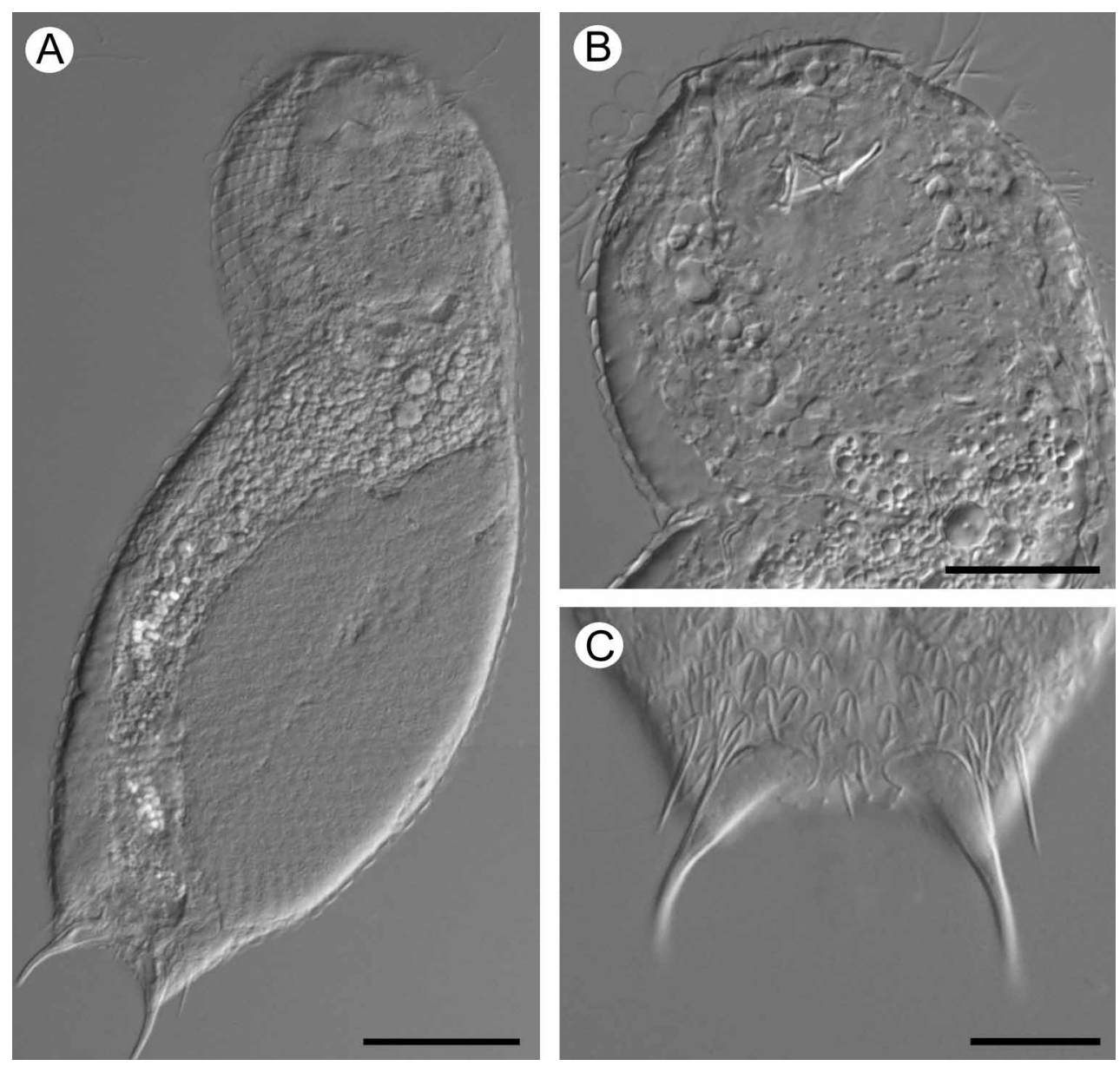

FIGURE 4. Aspidiophorus squamulosus. A) Habitus. B) Pharynx with cuticular reinforcements. C) Dorsal view of the furcal base showing distribution of scales and spines. Scale bars: A, $50 \mu \mathrm{m} ; \mathrm{B}, 20 \mu \mathrm{m} ; \mathrm{C}, 10 \mu \mathrm{m}$.

A large sized species with five-lobed head. Hypostomium well developed as a transverse cuticular bar. The dorsal scales are rhomboidal in shape. Three pairs of simple straight spines are present dorsally at the base of each furcal branch. In the Swedish specimen the middle spine is the shortest, which is in contrast to Roszczak (1969) and Schwank (1990) but in accordance with Kisielewski (1986). Moreover, the number of dorsal scale columns is approximately 28, which is in contrast to Schwank (1990) who states that there are 12-15 dorsal columns. This may be explained by the extremely compressed state under which the Swedish specimen was recorded. However, 
the total number of columns (including ventrolateral) are 45 and in accordance with Polish specimens found by Kisielewski (1986). The posterior trunk region is covered by apparently non-pedunculated keeled scales. In the caudal bifurcation some of these scales can be seen to carry short spines, perhaps corresponding to the bristles reported by Kisielewski (1986). Ventral interciliary area covered by alternating rows of keels. Ventral ciliation in two longitudinal bands; whether they merge on the head could not be seen. Pharynx, with cuticular reinforcements (Figure 4B), widens towards the pharyngeal intestinal junction.

Previously reported from Denmark (Grilli et al. 2010), Italy (Balsamo \& Tongiorgi 1995), Poland (Kisielewski 1998) and Sweden (Kånneby et al. 2009).

\section{Aspidiophorus tetrachaetus Kisielewski, 1986}

(Figure 5)

Localities. Lake Ånnsjön, Jämtland (N 63 15’35”; E $12^{\circ}$ 26' 51”); Small rockpool, Fiskebäckskil, Bohuslän (N 58 14'39"; E 11 27' 16").

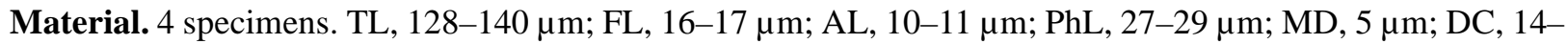
18; DR, 32-38; VC, 8; VTS, 8-9 x $4 \mu \mathrm{m}$; PL, 0.5-1 $\mu \mathrm{m}$.
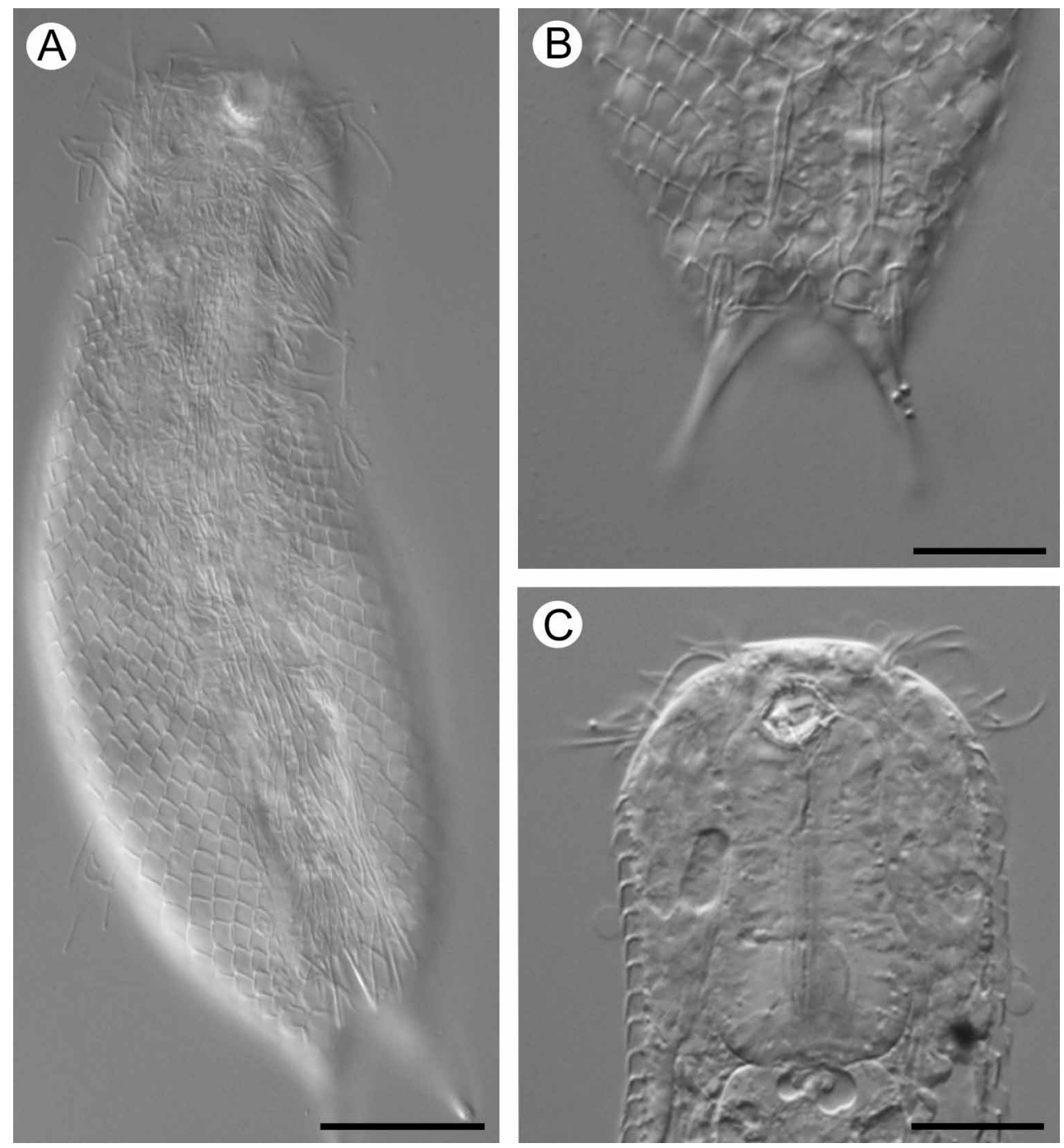

FIGURE 5. Aspidiophorus tetrachaetus. A) Ventral view. B) Dorsal view of scales and spines of posterior trunk region. C) Shape of pharynx. Scale bars: A, $20 \mu \mathrm{m}$; B and C, $10 \mu \mathrm{m}$.

A small sized species with weakly five-lobed head. Two pairs of sensory bristles; anterior pair anchored by papillae and posterior pair by double keeled scales. Dorsal scales are rhomboidal in shape with weakly rounded edges. Two pairs of characteristic simple spines are present in the posterior trunk region. Each spine of the longer 
anterior pair is $10-12 \mu \mathrm{m}$ in length and anchored by a scale with keels on either side of the spine base. The shorter posterior pair reaches 5-6 $\mu \mathrm{m}$ in length and is anchored by smaller scales just at the base of the furca. Interciliary field with approximately 8 columns of keels which can be followed up at least halfway the length of the pharynx. Paired ventral terminal keeled scales that widens toward the distal end. Ventral ciliation in two longitudinal bands not merging on the head. Pharynx, broad with large terminal swellings, posterior swelling larger than anterior.

Previously reported from Poland (Kisielewski 1998), Russia (Tretjakova 1989) and Sweden (Kånneby et al. 2009).

\section{Genus Heterolepidoderma Remane, 1927}

Heterolepidoderma joermungandri $\mathbf{n}$. sp.

(Figures 6, 7)

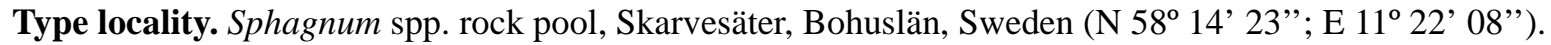

Type material. Photographs of five specimens, available at the Swedish Museum of Natural History, Stockholm, Sweden. Accession numbers: Holotype, SMNH Type-8134; Paratypes, SMNH Type-8135 - SMNH Type8138 .

Etymology. The species is named after the scaly Midgard serpent, believed to encircle the earth in Nordic mythology.

Diagnosis. Small species, 94-105 $\mu \mathrm{m}$ in total length. Body width 20-22 $\mu \mathrm{m}, 20-22 \mu \mathrm{m}, 32-37 \mu \mathrm{m}$ and $12 \mu \mathrm{m}$ at head, neck, trunk and base of furca, respectively. Five-lobed head with cephalion and well developed hypopleuria. Anterior sensory bristles anchored by papillae, posterior sensory bristles anchored by double keeled scales. Straight furca, 13-15 $\mu \mathrm{m}$ in length, with rather thin adhesive tubes pointing slightly outward at distal end. Dorsal body surface covered by keeled scales distributed in 21-22 columns with 22-23 scales in each. Columns converging in the narrow parts of the body. Ventral interciliary area with keels and 1 to 2 pairs of larger keeled scales with simple spines. Ventral ciliation in two separate longitudinal bands. Mouth subterminal. Pharynx 27-29 $\mu \mathrm{m}$ in length, with anterior and posterior swellings and two cuticular reinforcements.

Description. Heterolepidoderma joermungandri n. sp. is a small-sized species, $94-105 \mu \mathrm{m}$ in total body length. Head five-lobed, epipleuria barely visible while hypopleuria are well developed. Cephalion $12 \mu \mathrm{m}$ in width. Two pairs of cephalic ciliary tufts, two cilia are considerably longer than the rest and reach lengths of up to $16 \mu \mathrm{m}$. Ocellar granules absent.

Body width 20-22 $\mu \mathrm{m}$ at the head (U8-9), 20-22 $\mu \mathrm{m}$ at the neck (U31-33), 32-37 $\mu \mathrm{m}$ at the trunk (U64-67) and $12 \mu \mathrm{m}$ at the base of the furca (U88-90). Head slightly delimited from trunk by neck constriction that gradually widens into the trunk, which reaches its greatest width around U65-70. The trunk then tapers into a straight furca $13-15 \mu \mathrm{m}$ in length with rather thin adhesive tubes, $7-8 \mu \mathrm{m}$ in length, pointing slightly outward at their distal ends. Anterior and posterior sensory bristles present, anterior pair anchored by papillae at U24-25 and posterior pair anchored by double keeled scales at U82-86.

Dorsal body surface covered by 21-22 columns of 22-23 keeled scales with visible edges. The total number of columns is $34-38$. The median column of dorsal scales is straight, except in the narrowest part of the neck region where it is replaced by two columns of diagonally arranged scales, while the columns on either side converge toward the narrower parts of the body. Just at the base of the furcal branches a pair of large rounded scales is present and just posterior to these on the inner edge of each furcal branch is an additional pair of keeled scales. The dorsal scales are hemi-elliptical in shape, 5-6 $\mu \mathrm{m}$ in length and 2-3 $\mu \mathrm{m}$ in width; with a prominent keel approximately $0.5 \mu \mathrm{m}$ in height. The head and neck scales are more rhomboidal in shape, $4 \mu \mathrm{m}$ in length and $2-3 \mu \mathrm{m}$ in width. The interciliary area is covered by 7-10 columns of keels, scales apparently not developed, which can be followed past the pharyngeal intestinal junction. The posteriormost row (including terminal scales) consists of 2-4 larger keeled scales, approximately $5 \mu \mathrm{m}$ in length, with a simple spine. Ventral ciliation in two separate longitudinal bands, not merging on the head.

Mouth subterminal, 4-5 $\mu \mathrm{m}$ in diameter; pharynx 27-29 $\mu \mathrm{m}$ in length with anterior and posterior swellings. Anterior region of pharynx reinforced by two cuticular rods just behind the mouth. Pharyngeal intestinal junction at U31-32. Intestine straight, anus situated at U87. 
All observed specimens were adults in parthenogenetic phase.

Taxonomic remarks. Heterolepidoderma consists of 34 nominal species of which 20 are freshwater and 14 marine or brackish. Two species, H. fallax Remane, 1936 and H. loripes Martin, 1981, are considered species inquirendae (Balsamo et al. 2009).

Heterolepidoderma joermungandri $\mathbf{n}$. sp. shows morphological characteristics found in both freshwater and marine species of the genus. Heterolepidoderma jureiense Kisielewski, 1991 and H. dimentmani Kisielewski, 1999 are freshwater species with cuticular reinforcements in the anterior part of the pharynx. The latter species can be separated from $H$. joermungandri $\mathbf{n}$. sp. by its pronouncedly five-lobed head; moreover, the pharynx has two pairs of cuticular rods and an additional pair of cuticular granules compared to a single pair of cuticular rods and the absence of an additional pair of cuticular granules in $H$. joermungandri $\mathbf{n}$. sp.

The pharynx in several marine species is reinforced with cuticular elements: Heterolepidoderma axi Mock, 1979, H. clipeatum Schrom, 1972, H. contectum Schrom, 1972 and H. foliatum Renaud-Mornant, 1967 all have hydrofoil scales which are absent in $H$. joermungandri $\mathbf{n}$. sp. Marine species without hydrofoil scales but with cuticular reinforcements in the pharynx are H. armatum Schrom, 1966, H. arenosum Kisielewski, 1988, H. hermaphroditum Wilke, 1954 and H. istrianum Schrom, 1972. H. armatum and H. istrianum are of a similar size but have fewer dorsal scale columns, 16-17 and 12-13 respectively vs. 21-22 and a different arrangement of head lobes compared to $H$. joermungandri $\mathbf{n}$. sp. $H$. arenosum can be separated from the new species on the basis of possessing large ocellar granules and a longer furca and $H$. hermaphroditum on the basis of its clearly five-lobed head. H. caudosquamatum Grilli, Kristensen and Balsamo, 2009, a brackish species described from Denmark, has hydrofoil scales and a lower total number of scale columns.
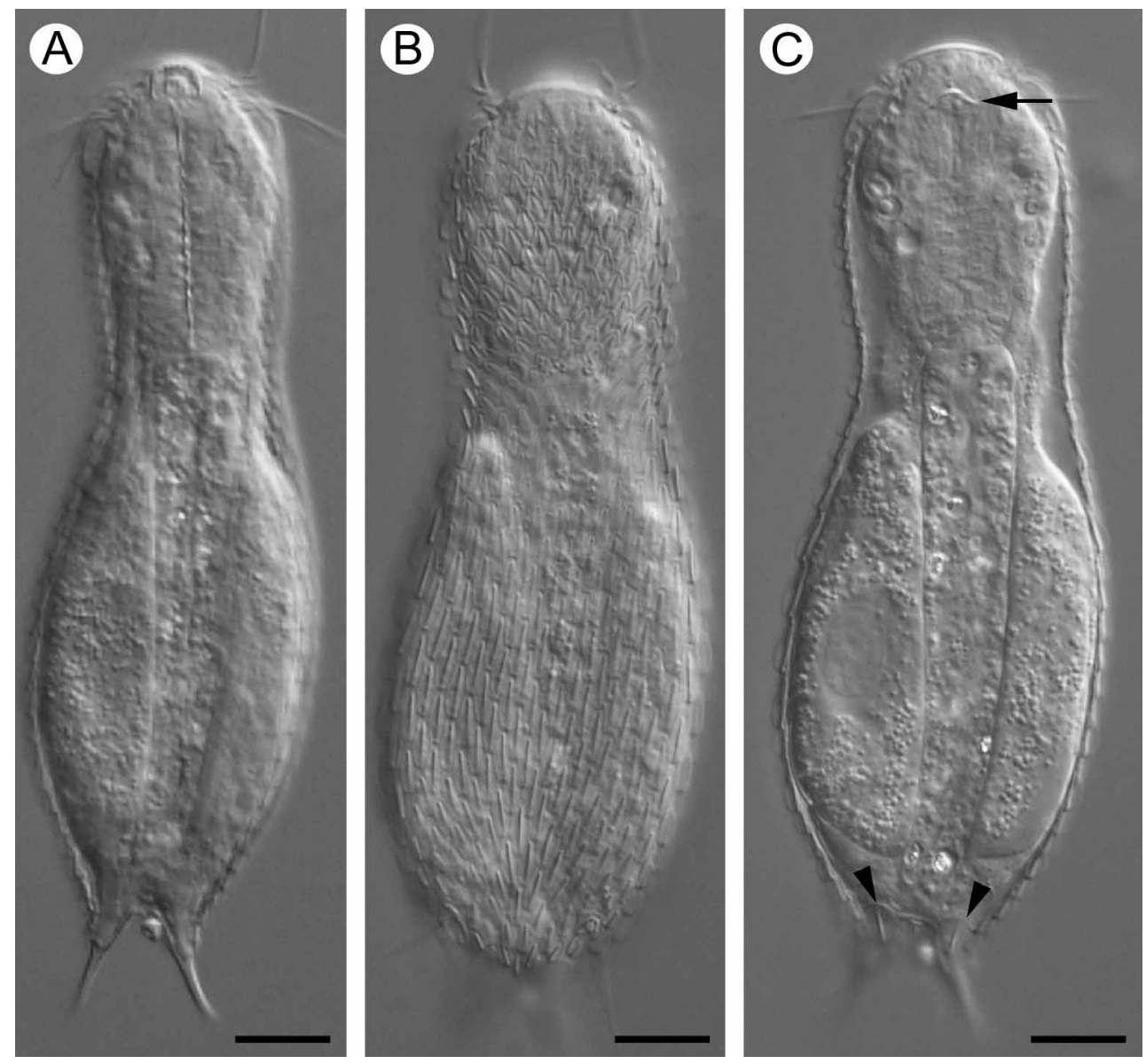

FIGURE 6. Heterolepidoderma joermungandri n. sp. A) Habitus. B) Dorsal view of distribution and shape of scales. C) Habitus, arrow indicates cuticular reinforcement of pharynx and arrow heads indicate scales of the furcal base. Scale bars: A$\mathrm{C}, 10 \mu \mathrm{m}$. 

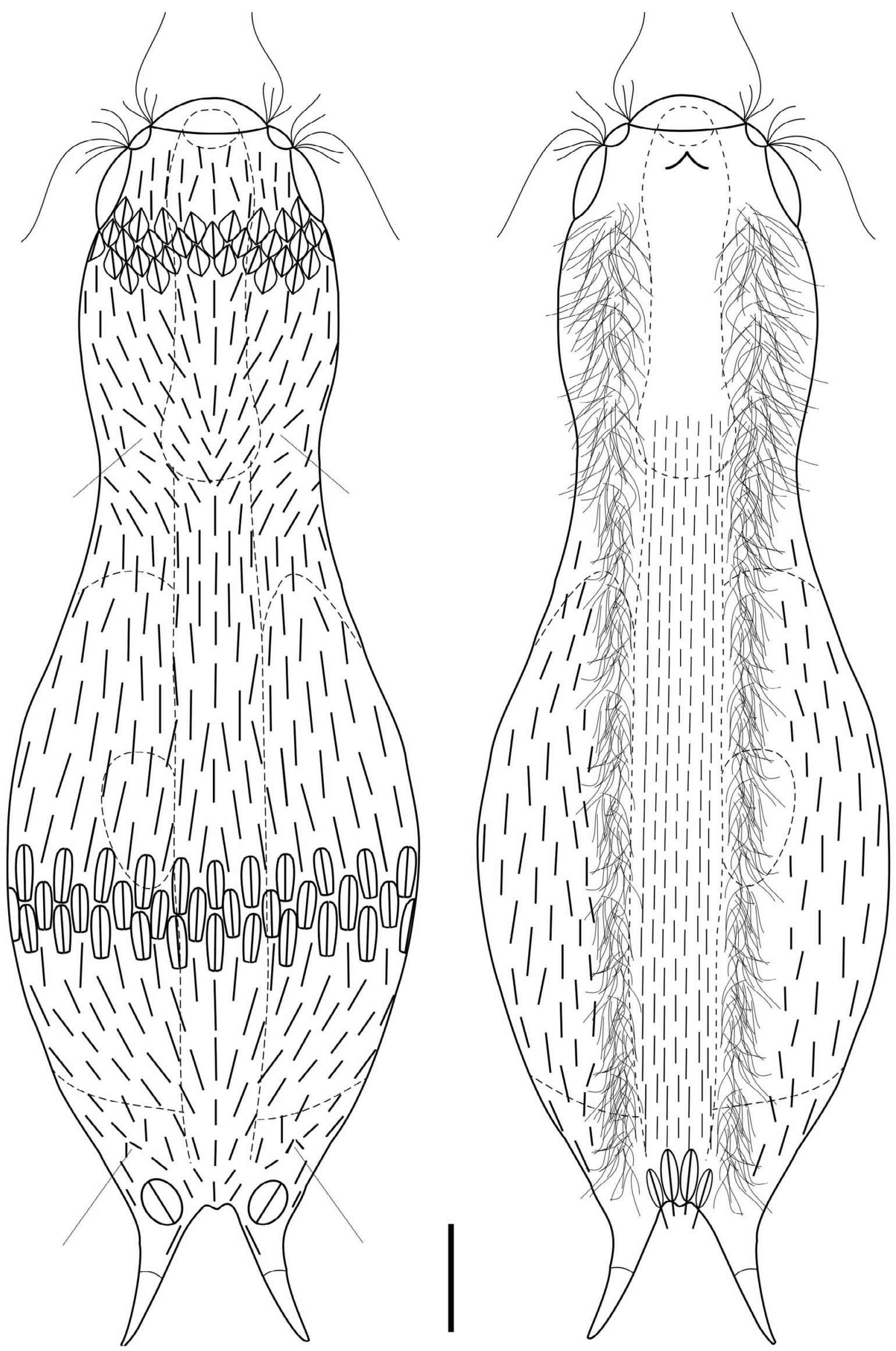

FIGURE 7. Schematic drawing of Heterolepidoderma joermungandri n. sp. Dorsal view to the left and ventral view to the right. Scale bar: $10 \mu \mathrm{m}$. 
Of all the hitherto discussed species, $H$. joermungandri n. sp. seems morphologically most closely related to $H$. jureiense. Both species have similar body shapes and morphological and morphometric characters. However, $H$. jureiense has hydrofoil scales, which are absent in H. joermungandri n. sp., and has so far only been reported from Brazil.

\section{Heterolepidoderma macrops Kisielewski, 1981}

(Figure 8)

Localities. Freshwater Sphagnum spp. rockpool, Hållö (N 58 20'00”; E $11^{\circ} 12^{\prime}$ 50”); A small pond close to lake Torneträsk at Abisko Scientific Research Station, Abisko, Lapland (N 68 21' 19"; E 18 49' 21'); Among moss, Björkliden, Lapland (N 68 24' 25'"; E 18 41'36”).

Material. 5 specimens. TL, 143-150 $\mu \mathrm{m}$; FL, $17 \mu \mathrm{m}$; AL, $10 \mu \mathrm{m}$; PhL, 33-37 $\mu \mathrm{m}$; MD, $4 \mu \mathrm{m}$; DC, 27-33; DR, 30; TS, 5 x 1-2 $\mu \mathrm{m}$; VTS, 4.5 x $2.5 \mu \mathrm{m}$.
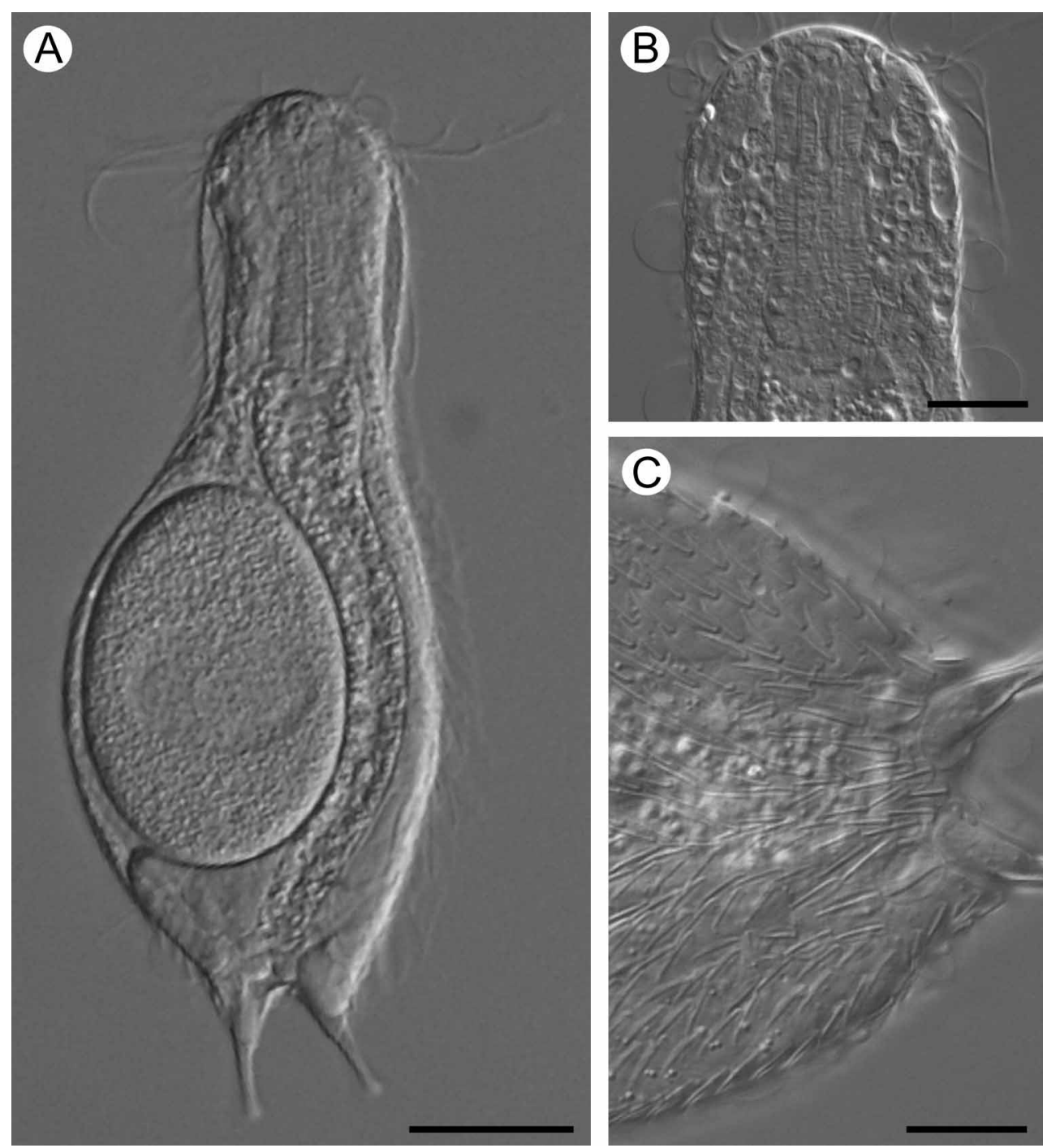

FIGURE 8. Heterolepidoderma macrops. A) Habitus. B) Shape of pharynx and ocellar granules. C) Dorsal view of posterior trunk region showing distribution of scales. Scale bars: A, $20 \mu \mathrm{m} ; \mathrm{B}, 15 \mu \mathrm{m} ; \mathrm{C}, 10 \mu \mathrm{m}$.

Mid sized species with rounded to five-lobed head, characterized by two large ocellar granules. Two pairs of dorsal sensory bristles, posterior pair anchored by double keeled scales. Dorsal body surface covered by elongated elliptical keeled scales without spines. Scales are ordered parallel to the body outline except for the median column which is more or less straight. Interciliary area naked except for two keeled ventral terminal scales. Ventral ciliation 
in two longitudinal bands that are further divided on the head, but do not merge. Pharynx with weak swellings at both ends. The number of dorsal columns and the length of Swedish specimens are close to or just above the upper limit of literature data.

Previously recorded from France (Kisielewski 1998), Germany (Schwank 1990), Poland (Kisielewski 1998), Russia (Tretjakova 1989) and perhaps United States and Japan (Schwank 1990).

\section{Heterolepidoderma ocellatum (Metschnikoff, 1865)}

(Figure 9)

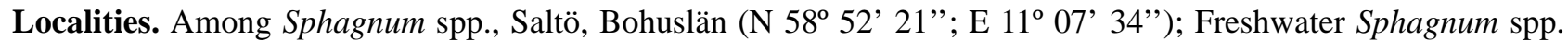

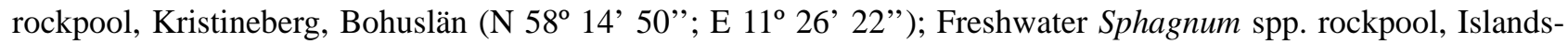

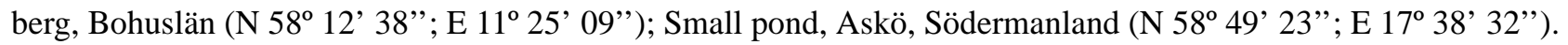

Material. 14 specimens. TL, 114-127 $\mu \mathrm{m}$; FL, 14-15 $\mu \mathrm{m}$; AL, 7-8 $\mu \mathrm{m}$; PhL, 31-34 $\mu \mathrm{m}$; MD, $4-5 \mu \mathrm{m}$; DC, 14-17; DR, 20-22; TS, 5-6 x 2-3 $\mu$ m; VTS, 5-6 x 2-3.

A relatively small sized species, with five-lobed head and a pair of ocellar granules. Sporadic absence of ocellar granules have been reported in some populations (Schwank 1990; Fregni et al. 1998). Two pairs of sensory bristles present, each of the posterior pair anchored by a double-keeled scale. Dorsal body surface covered by elongated elliptical keeled scales, smaller in size in head and neck regions. Interciliary area naked except for a pair of keeled terminal scales and 1-2 transverse rows of 3-4 keeled scales. Pharynx with small swellings at both ends.

Two of the Swedish specimens were in post-parthenogenetic phase with X-organ and sperm present (Figure 9A). Another peculiarity is that several specimens had more or less well developed short ventrolateral spines. In one specimen, the area between the edges of the posterior lateral parts of the scale appeared to be depressed giving the appearance of a tri-lobed scale. The keels were not modified in this part but instead gave the impression of a short spine. Whether the keel was actually in contact with the depressed area could not be determined.
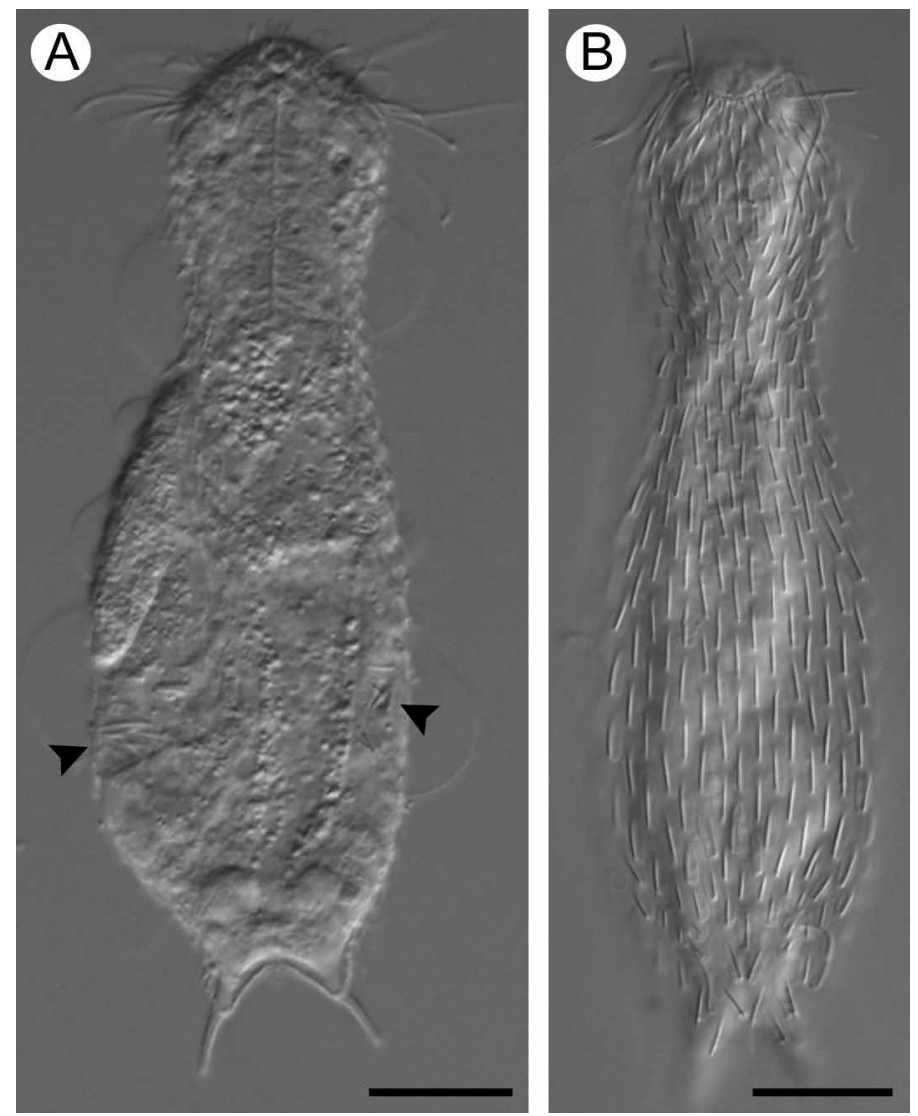

FIGURE 9. Heterolepidoderma ocellatum. A) Habitus, arrowheads indicate spermatozoa. B) Dorsal view, showing distribution of scales. Scale bars: $15 \mu \mathrm{m}$. 
This species is widely distributed in Europe (see e. g. Greuter 1917; Mola 1932; Remane 1935-36; Valkanov 1937; Rudescu 1967; Martin 1981; Schwank 1990; Kisielewski 1998) and is also reported from Canada (Schwank 1990), United States (Schwank 1990), Japan (Saito 1937) and Brazil (Kisielewski 1991).

\section{Heterolepidoderma trapezoidum n. sp.}

(Figures 10, 11)

Type locality. Small stream, Mount Snasahögarna, Jämtland, Sweden (N 63 12'39”; E $\left.12^{\circ} 18^{\prime} 19^{\prime \prime}\right)$.

Type material. Photographs of one specimen, available at the Swedish Museum of Natural History, Stockholm, Sweden. Accession number: Holotype, SMNH Type-8139.

Etymology. This species is named after its peculiar head-shape which from the dorsal side resembles an isosceles trapezoid.

Diagnosis. Body length $133 \mu \mathrm{m}$, body width $31 \mu \mathrm{m}, 20 \mu \mathrm{m}, 38 \mu \mathrm{m}$ and $9 \mu \mathrm{m}$ at head, neck, trunk and base of furca respectively. Head with well developed hypopleuria and well delimited from trunk by a constricted neck. Posterior trunk region greatly reduced in width. Furca straight, $14 \mu \mathrm{m}$ in length, with adhesive tubes pointing slightly outward at their distal ends. Anterior sensory bristles absent, posterior sensory bristles present. Dorsal body surface covered by suboval to round scales, with poorly developed edges, distributed in 16-17 columns with 22-24 scales in each. Dorsal scales absent above anterior part of pharynx, scales on either side of this area are hemi-elliptical and arranged diagonally relative to the longitudinal body axis. Ventral interciliary area naked except in the posterior part where thin, smooth, round, reduced and overlapping scales are present. Pharynx without swellings, $37 \mu \mathrm{m}$ in length.
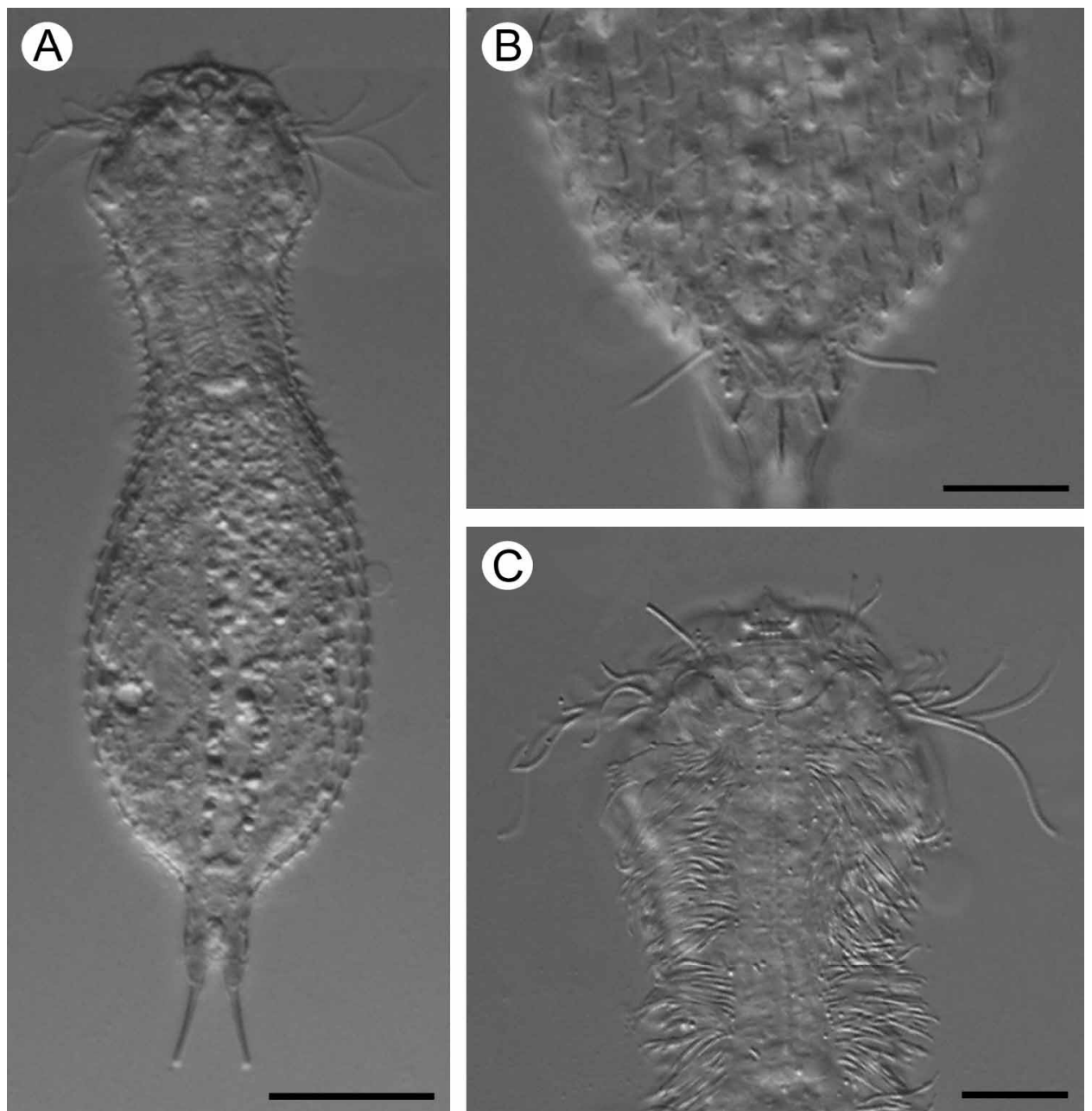

FIGURE 10. Heterolepidoderma trapezoidum n. sp. A) Habitus. B) Dorsal view of scales and anterior part of furcal base. C) Ventral view of head and neck region showing ventral ciliation and the smooth kidney-shaped hypostomium. Scale bars: A, 20 $\mu \mathrm{m} ; \mathrm{B}$ and $\mathrm{C}, 10 \mu \mathrm{m}$. 


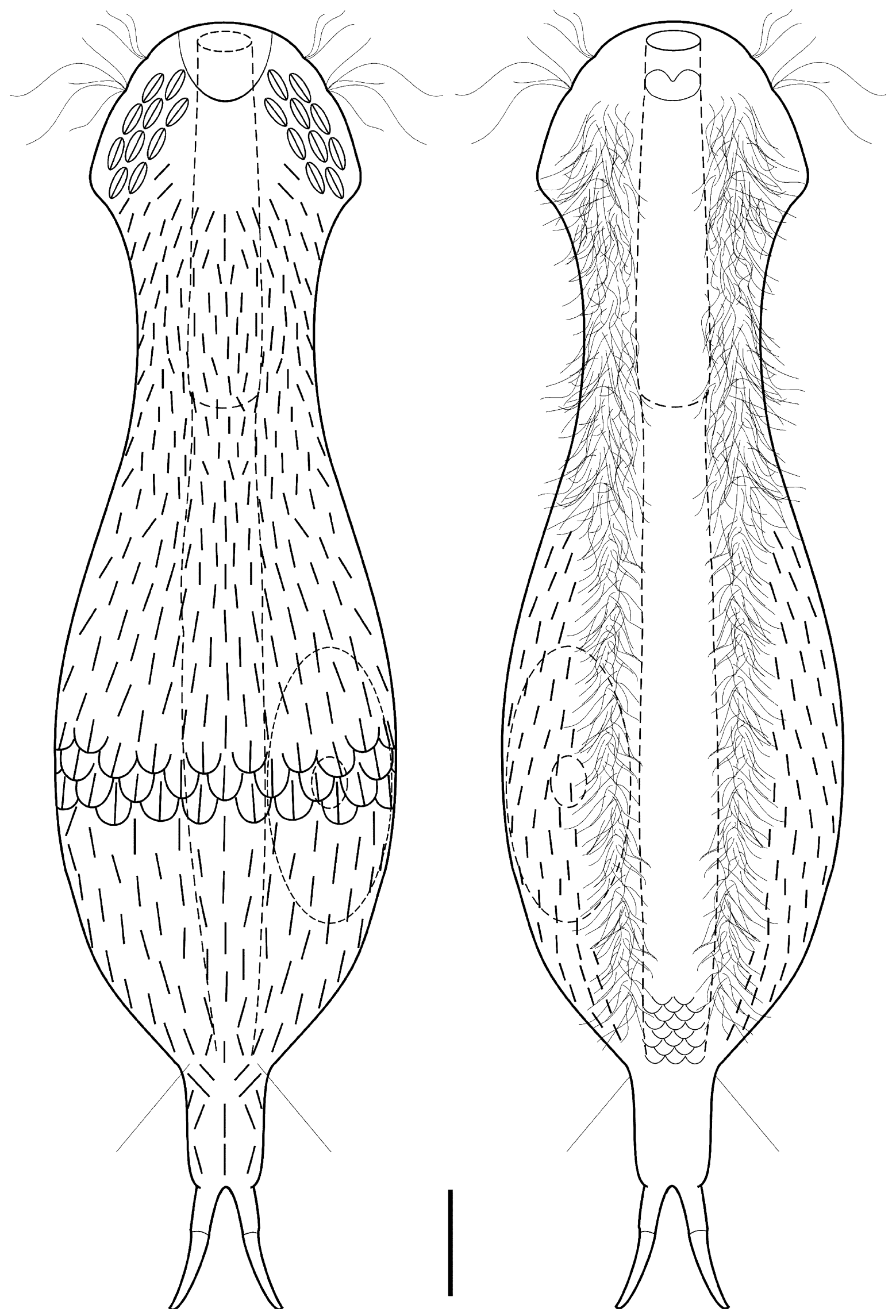

FIGURE 11. Schematic drawing of Heterolepidoderma trapezoidum n. sp. Dorsal view to the left and ventral view to the right. Scale bar: $10 \mu \mathrm{m}$. 
Description. Heterolepidoderma trapezoidum $\mathbf{n}$. sp. is a mid-sized species, $133 \mu \mathrm{m}$ in total body length. Head appears three-lobed but is weakly five-lobed, shaped as an isosceles trapezoid. Cephalion $14 \mu \mathrm{m}$ in width, epipleuria barely visible while hypopleuria are large and well developed. Hypostomium present as a smooth kidneyshaped plate just behind the mouth. Two pairs of cephalic ciliary tufts present. The cilia of the posterior tufts are approximately $20 \mu \mathrm{m}$ in length and those of the anterior tufts 5-8 $\mu \mathrm{m}$ in length. Ocellar granules absent.

Body width $31 \mu \mathrm{m}$ at the head (U14), $20 \mu \mathrm{m}$ at the neck (U26), $38 \mu \mathrm{m}$ at the trunk (U60) and $9 \mu \mathrm{m}$ at the base of the furca (U81-87). Head well delimited from trunk by a constricted neck, which gradually widens into the trunk. The posterior trunk region is drastically reduced in width from $38 \mu \mathrm{m}$ at U60 to $9 \mu \mathrm{m}$ at U81, into a tapered furca base. The furca is more or less straight, $14 \mu \mathrm{m}$ in length. Adhesive tubes $11 \mu \mathrm{m}$ in length, almost parallel, pointing slightly outward at their distal ends. Anterior sensory bristles apparently absent, posterior sensory bristles anchored by papillae at U82.

Dorsal body surface covered by suboval to round keeled partially overlapping scales distributed in 16-17 columns with 22-24 scales in each column. The edges of the scales are poorly developed and may be partly fused with the cuticle. The dorsal part of the head above the pharynx and down half the length of the pharynx naked. The number of scales per column was counted from the posterior end of this naked area. The scales situated laterally on either side of the naked portion are hemi-elliptical, half as wide as long and diagonally arranged relative to the longitudinal body axis. The median dorsal scale column is straight while the columns on either side tend to diverge, progressively approaching parallelism with the lateral body outline. Just anterior of the caudal cutting there are two medial keeled scales. The base of the furca also bears two pairs of dorsal keeled scales diagonally arranged relative to the longitudinal body axis, the outer pair being half the size of the inner pair. Two pairs of larger keeled dorsolateral scales are also present on the furca. Ventrolaterally in the anterior portion of the body, the keels form short stout spines. These spines become progressively fused with the scales towards the posterior end. The posterior part of the ventral interciliary area with apparently weakly developed, rounded, smooth, reduced, partially overlapping scales. Ventral ciliation in two separate longitudinal bands not merging on the head.

Mouth terminal, $4 \mu \mathrm{m}$ in diameter. Cylindrical pharynx, $37 \mu \mathrm{m}$ in length, widens slightly towards the pharyngeal intestinal junction which is situated at U30. Intestine straight, anus at U80.

The observed specimen was an adult in parthenogenetic phase.

Taxonomic remarks. The new species can be affiliated with either Heterolepidoderma or Chaetonotus. In Chaetonotus, C. silvaticus (Varga, 1963), has a similar body shape to Heterolepidoderma trapezoidum $\mathbf{n}$. sp., with a constricted neck and a tapering caudal section. However, $C$. silvaticus has a much greater number of dorsal scales, distributed in 28-32 columns with 50-60 scales in each compared to 16 columns with 22-24 scales in each for $H$. trapezoidum n. sp. Moreover, the adhesive tubes of $C$. silvaticus are significantly longer and of different shape than in H. trapezoidum $\mathbf{n}$. sp. The new species has short ventrolateral spines that progressively fuse with the scales towards the posterior end. The dorsal scales are keeled without spines and in absence of further evidence (e. g. molecular data) this species is provisionally considered a member of Heterolepidoderma. H. trapezoidum n. sp. can be separated from all hitherto described species of the genus on the basis of its elongated furcal base and the presence of a dorsal apparently naked region above the pharynx. Of the described species within the genus $H$. trapezoidum n. sp. seems closest to H. famaillensis Grosso \& Drahg, 1991 and H. longicaudatum Kisielewski, 1979. H. famaillensis has a somewhat similar head-shape with small epipleuria and a kidney-shaped hypostomium. H. longicaudatum has similar trunk scales and a naked fairly elongated furcal base.

\section{Genus Lepidochaetus Kisielewski, 1991}

\section{Lepidochaetus zelinkai (Grünspan, 1908)}

(Figure 12)

Localities.: Small stream, Mount Snasahögarna, Jämtland (N 63 12’ 39”; E 12 18' 19”); Small pond, Askö, Södermanland (N 58 49' 23”; E 17 38' 32"); Freshwater rockpool among Sphagnum spp., Hållö, Bohuslän (N

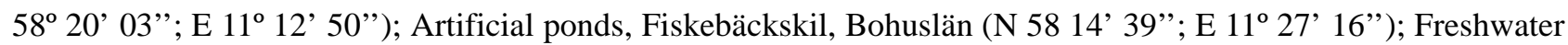
rockpool, Runmar, Stockholm archipelago (N 59 17' 22"; E 18 47' 56”); Small lake, Highway E10, Lapland (N

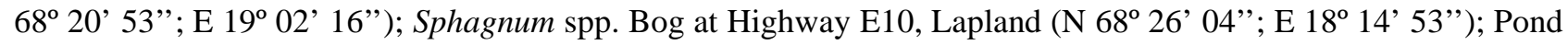
south of Lake Torneträsk, Abisko, Lapland (N 68²1' 19"; E 18 49' 21"). 
Material. 8 specimens. TL, 242-309 $\mu \mathrm{m}$; FL, 30-35 $\mu \mathrm{m}$; PhL, 50-62 $\mu \mathrm{m}$; MD, 9-12 $\mu \mathrm{m}$; DC, 10-12 DR, 35$36 \mathrm{VC}, 6-8$.

Long and slender species, with hammer-shaped, three- to five-lobed head, with large cephalion. Dorsal scales are elliptical to heart-shaped and partially overlapping. Three pairs of long rigid bifid spines and a single median bifid spine, all in posterior dorsal trunk region overshooting the furcal branches, are characteristic of the species. The other dorsal spines are simple or, especially in the posterior trunk region, have less well developed denticles. Interciliary area is covered by oval keeled scales carrying short simple spines, except for the terminal end which is covered by a couple of larger scales with longer spines. The Swedish specimens fall well within the ranges presented in the literature.

This species is widely distributed in Europe (see e. g. Grünspan 1908; Greuter 1917; Rudescu 1967; Martin 1981; Schwank 1990; Balsamo \& Tongiorgi 1995; Kisielewski 1998) and is also reported from Japan (Sudzuki 1971), Korea (Lee \& Chang 2000), Canada (Schwank 1990), Argentina (Grosso 1976) and Brazil (Kisielewski 1991).
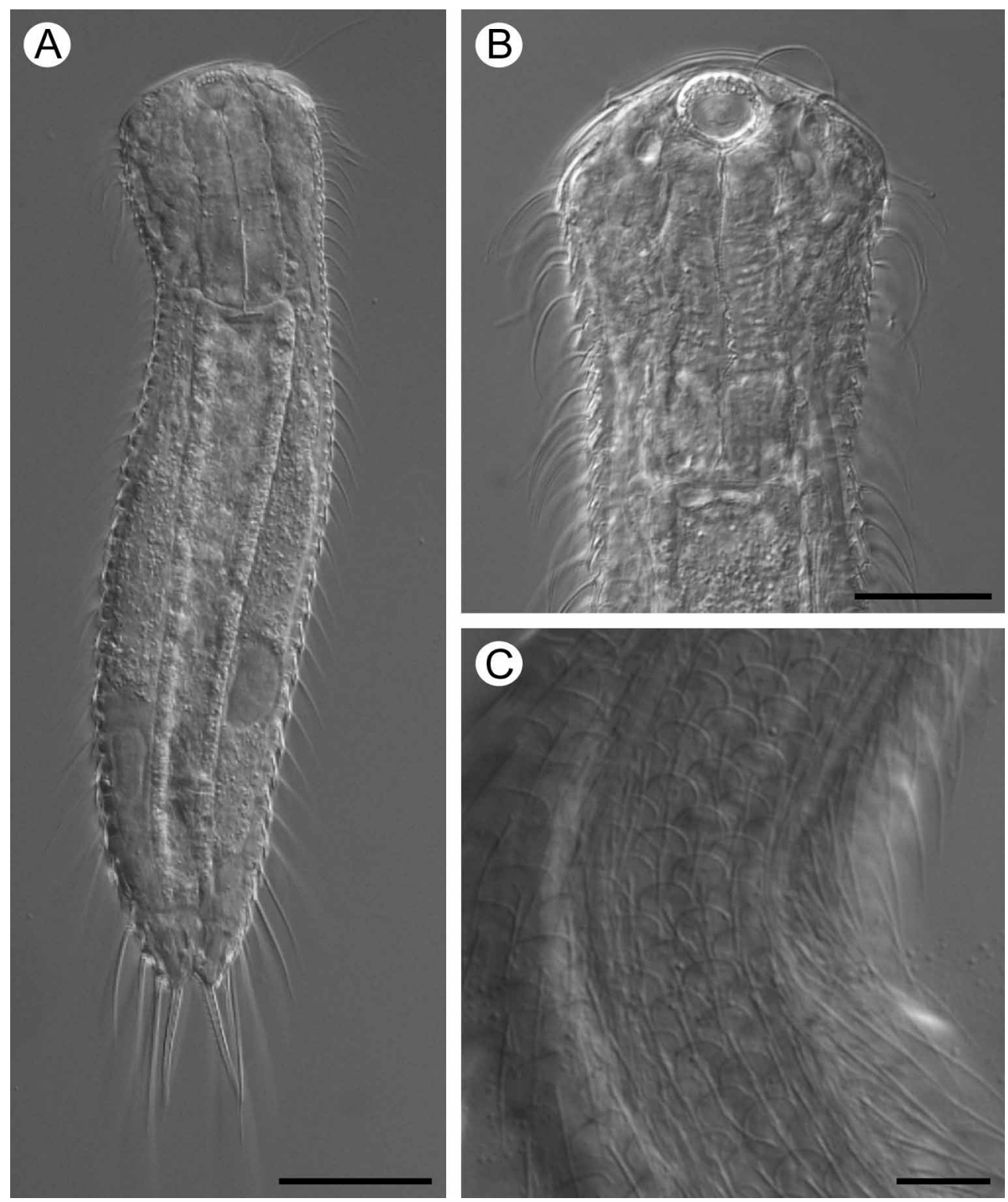

FIGURE 12. Lepidochaetus zelinkai. A) Habitus. B) Shape of pharynx and mouth. C) Dorsal view of mid-trunk region showing distribution of spined scales. Scale bars: A, $40 \mu \mathrm{m} ; \mathrm{B}, 20 \mu \mathrm{m}$ and C, $10 \mu \mathrm{m}$. 


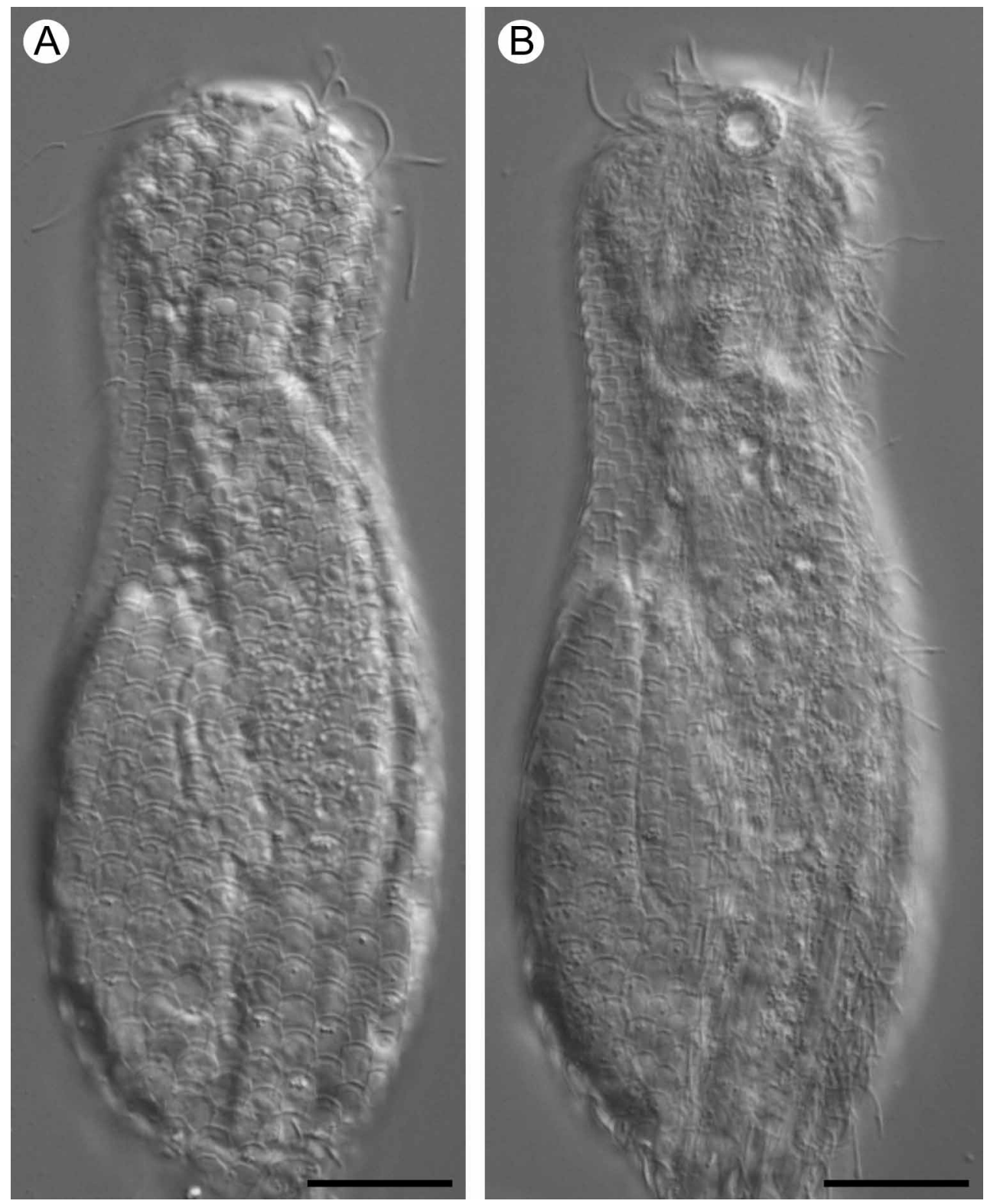

FIGURE 13. Lepidodermella minor minor. A) Dorsal view. B) Ventral view. Scale bars: $20 \mu \mathrm{m}$.

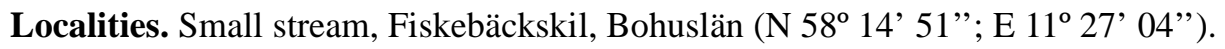

Material. 1 specimen. TL, $130 \mu \mathrm{m}$; FL, $16 \mu \mathrm{m}$; AL, $9 \mu \mathrm{m}$; PhL, $25 \mu \mathrm{m}$; MD, $6 \mu \mathrm{m}$; DC, 11; DR, 35-36; VC, $\mathrm{Na}$; TS, 5 x $5 \mu \mathrm{m}$; VTS, Na.

Lepidodermella minor minor is an insufficiently described species. The head is indistinctly five-lobed. Two pairs of cephalic sensory ciliary tufts, the posterior pair longer than the anterior pair. Two pairs of sensory bristles are present, the posterior pair anchored by double-keeled scales. The dorsal side is covered by rounded pentagonal to hexagonal scales. Because the anterior and posterior parts of two subsequent scales in a column overlap, all scales show a more or less well developed double anterior edge which is more prominent in the posterior trunk region. The specimen was in rather bad shape, and the ventral side could not be sufficiently studied, but the keels of the ventral terminal scales were nevertheless barely visible. Mouth subterminal, pharynx very short and rather thick connected via the pharyngeal intestinal junction (at U23) to the straight intestine. The Swedish specimen did not 
show the cuticular teeth present in German and Polish specimens (see Kisielewski, 1981). However, it follows the morphological and morphometric data presented by Kisielewski (1981) very well and it is therefore considered $L$. minor minor.

Previously reported from Germany (Remane 1935-36) and Poland (Kisielewski 1998).

\section{Lepidodermella squamata (Dujardin, 1841)}

(Figure 14)
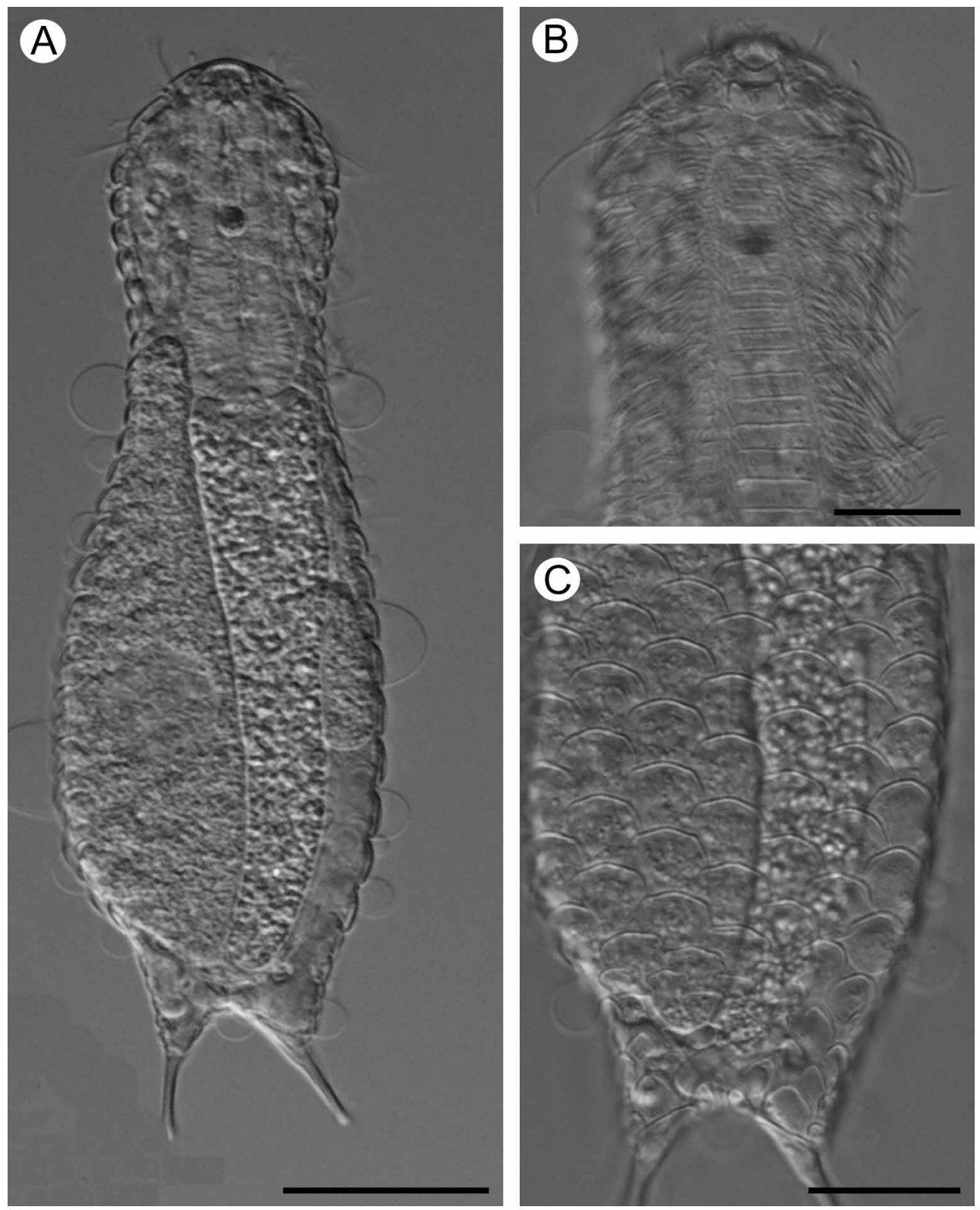

FIGURE 14. Lepidodermella squamata. A) Habitus. B) Ventral view of head and neck region showing the transverse scales of the interciliary area. C) Dorsal view of trunk showing shape and distribution of scales. Scale bars: A, $30 \mu \mathrm{m} ; \mathrm{B}, 15 \mu \mathrm{m} ; \mathrm{C}, 20 \mu \mathrm{m}$.

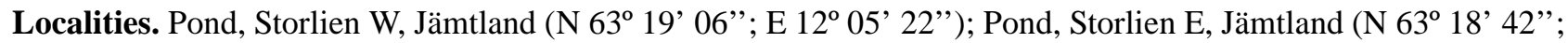

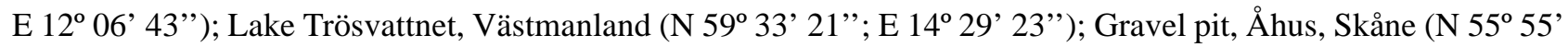

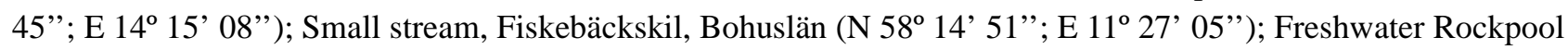
among Sphagnum spp., Hållö, Bohuslän (N 58²0'00”; E $11^{\circ} 12^{\prime}$ 50”) Artificial pond, Nybro, Småland (N 56º

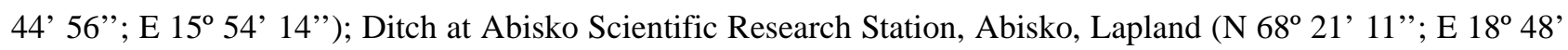
54'); Meadow west of Abisko Scientific Research Station, Abisko, Lapland (N 68 21' 18'; E 18 48'40”); 
Among Sphagnum spp., Mount Njulla, Lapland (N 68 21' 36"; E $18^{\circ} 43^{\prime}$ 02"); Roadside ditch, Highway E10,

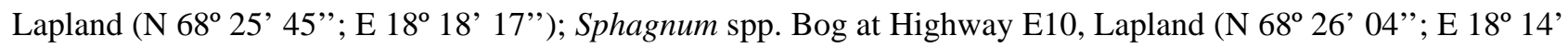
$53 ")$.

Material. 14 specimens. TL, 155-179 $\mu \mathrm{m}$; FL, 18-24 $\mu \mathrm{m}$; AL, 12-15 $\mu \mathrm{m}$; PhL, 46-52 $\mu \mathrm{m}$; MD, 4-7 $\mu \mathrm{m}$; DC, 7-9; DR, 28-30; VC, 5; VB, 20-24 ; TS, 6.5-8 x 6.5-9 $\mu \mathrm{m}$; VTS, 12-14 x 6-7 $\mu \mathrm{m}$.

Small to mid sized species with weakly five-lobed head. Hypostomium with two hooks. Dorsal head and trunk surface covered by smooth scales with either rounded or squared posterior edge; in the neck region the scales are more rectangular. The species is easily separated from the other species of the genus by a longitudinal series of more than 20 transverse cuticular plates below the pharynx and part of the anterior intestine. Interciliary area of the trunk with five columns of smooth more or less rounded quadrangular scales, or rounded equally sized scales. If interciliary scales are of different sizes, those of the medial column are the largest while the scales of the other columns decrease in size towards the ciliary bands. A pair of large keeled terminal scales and several smaller round scales are present ventrally at the posterior end. Ventral ciliation in two separate longitudinal bands. Pharynx gradually widens towards the pharyngeal intestinal junction. The Swedish specimens fall within the ranges of previously reported literature data.

A very common species widely distributed in Europe (see e. g. Marcolongo 1910; Greuter 1917; Remane 1935-36; Valkanov 1937; Rudescu 1967; Martin 1981; Schwank 1990; Kisielewski 1998) and also reported from India (Naidu \& Rao 2004), Japan (Saito 1937; Sudzuki 1975), Korea (Lee \& Chang 2000), Israel (Kisielewski 1999), East Africa (Daday 1910), Canada (Schwank 1990), United States (see e. g. Brunson 1950; Evans 1993) Brazil (Kisielewski 1991), Uruguay (Cordero 1918) and Argentina (Grosso \& Drahg 1984).

\section{Genus Polymerurus Remane, 1927}

\section{Polymerurus nodicaudus (Voigt, 1901)}

(Figure 15)

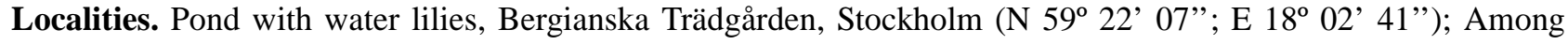
Phragmites sp. and Typha sp., Lower Lake Rudan, Handen, Södermanland (N 59 09' 27”; E $18^{\circ} 07^{\prime}$ 31'”).

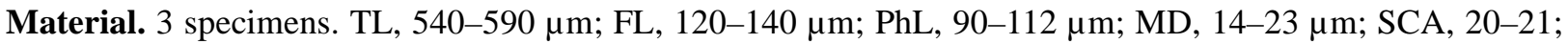
DC, 20-22; VR, 55; VC, 12-14.

Large elongated species with three-lobed head. Cephalion and hypostomium well developed, the latter forming a transverse concave bar behind the mouth. Furca long with adhesive tubes divided into 20-21 segments. Dorsal body surface covered by pentagonal to hexagonal spined scales. Spines suddenly increase in length posterior of the caudal cutting. Interciliary area covered by smaller scales, similar in shape to the dorsal ones, with short simple spines that increase in length towards the posterior end. Ventral ciliation in two longitudinal bands connected by a thin transverse ciliated band just behind the hypostomium. Pharynx widens towards the pharyngeal intestinal junction. The Swedish specimen falls within the ranges of previously reported literature data.

This species is widely distributed in Europe (see e. g. Marcolongo 1910; Valkanov 1937; Rudescu 1967; Martin 1981; Schwank 1990; Kisielewski 1998) and is also reported from India (Naidu \& Rao 2004), Israel (Kisielewski 1999), Japan (Saito 1937; Sudzuki 1975), Korea (Lee \& Chang 2000), Canada (Schwank 1990), United States (Bryce 1924; Davison 1938), Brazil (Kisielewski 1991) and Australia (Hochberg 2005). 


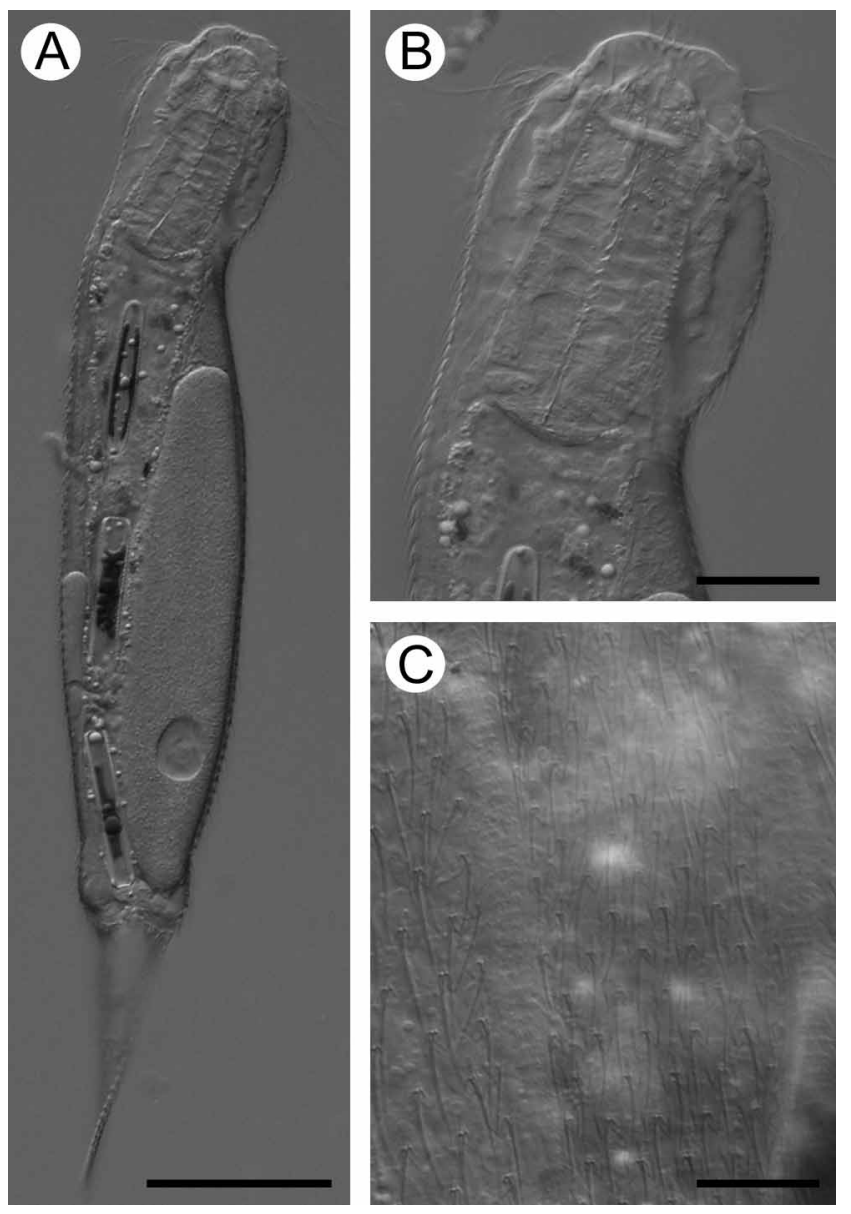

FIGURE 15. Polymerurus nodicaudus. A) Habitus. B) Shape of pharynx, mouth and hypostomium. C) Ventral view showing ventrolateral spined scales and the spined scales of the interciliary area. Scale bars: A, $100 \mu \mathrm{m} ; \mathrm{B}, 40 \mu \mathrm{m} ; \mathrm{C}, 15 \mu \mathrm{m}$.

\section{Polymerurus rhomboides (Stokes, 1887)}

(Figure 16)

Localities. Lake Trösvattnet, Västmanland (N 59³3' 21"'; E 14²9' 23”).

Material. 1 specimen. TL, $273 \mu \mathrm{m}$; FL, $80 \mu \mathrm{m}$; PhL, $50 \mu \mathrm{m}$; MD, $13 \mu \mathrm{m}$; DC, 20-22; DR, >50; SCA, 18; TS, 6-7 x 3; VC, 10.

Large elongated species with three-lobed head and well developed cephalion and pleuria. Hypostomium well developed as a transverse bar behind the subterminal mouth. Furca very long, divided into 18 segments. Body covered by oval smooth stalked scales without spines. Interciliary area covered by smaller scales similar in shape to the dorsal ones. Ventral ciliation in two longitudinal bands. Pharynx widens towards the pharyngeal intestinal junction. The Swedish specimen falls within the ranges of previously reported literature data.

This species is widely distributed in Europe (see e. g. Marcolongo 1910; 1914; Mola 1932; Valkanov 1937; Rudescu 1967; Martin 1981; Schwank 1990; Kisielewski 1998) and is also reported from Israel (Kisielewski 1999), Japan (Saito 1937), Korea (Lee \& Chang 2000); Cameroon (Togouet Zébaz et al. 2007), Canada (Schwank 1990), United States (Stokes 1887; Davison 1938; Anderson \& Robbins 1980), Argentina (Grosso 1975; Grosso \& Drahg 1983), Brazil (Kisielewski 1991) and Australia (Hochberg 2005). 


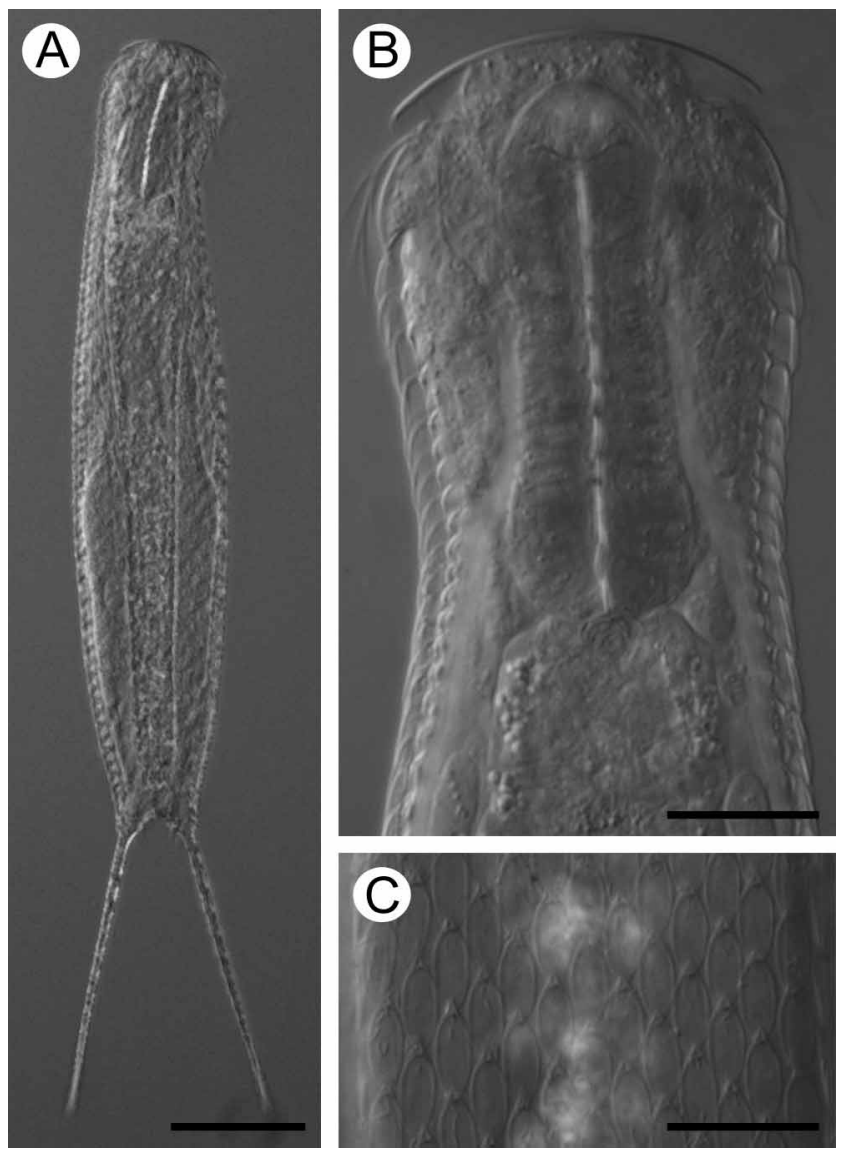

FIGURE 16. Polymerurus rhomboides. A) Habitus. B) Shape of pharynx and cephalion. C) Dorsal view of mid-trunk showing scales. Scale bars: A, $50 \mu \mathrm{m}$; B and C, $20 \mu \mathrm{m}$.

\section{Family Dasydytidae Daday, 1905}

\section{Genus Haltidytes Remane 1936}

\section{Haltidytes crassus (Greuter, 1917)}

(Figure 17)

Localities. Artificial pond, Nybro, Småland (N 56 44' 89"; E 15 54' $27^{\circ}$ ').

Material. 4 specimens. TL, 97-130 $\mu \mathrm{m}$; PhL, 35-40 $\mu \mathrm{m}$; DSL, 100-120 $\mu \mathrm{m}$; VSL, 120-162 $\mu \mathrm{m}$.

This species is characterized by three pairs of ventral spines; the posterior pair is the longest. Dorsally five pairs of spines are present; the anterior three pairs originate ventrolaterally while the posterior two pairs originate from the ventral side. Interciliary area naked. Locomotory ciliation in two longitudinal bands, each band further divided into tufts, and three semi-circular bands on the head. The Swedish specimens correspond well to the specimens found in Poland (Kisielewski, 1981) and Denmark (Grilli et al., 2010).

Previously reported from Italy (Balsamo \& Tongiorgi 1995), Romania (Rudescu 1967), Russia (Preobrajenskaja 1926; Tretjakova 1991), Switzerland (Greuter 1917), Denmark (Grilli et al. 2010), Canada (Schwank 1990), Brazil (Kisielewski 1991) and Argentina (Grosso 1973; Grosso \& Drahg 1983). 


\section{Genus Stylochaeta Hlava, 1904}

\section{Stylochaeta scirtetica Brunson, 1950}

(Figure 18)

Localities. Artificial pond, Nybro, Småland (N 56 44' 56"; E 15 54' 14”).

Material. 2 specimens. TL, $175 \mu \mathrm{m}$; CL, $5 \mu \mathrm{m}$; PhL, $33 \mu \mathrm{m}$; MD, $10 \mu \mathrm{m}$; SG1, $160 \mu \mathrm{m}$; SG2, 70-100 $\mu \mathrm{m}$; SG3, 80-90 $\mu \mathrm{m}$; SG4, $20 \mu \mathrm{m}$.

Large sized species with three-lobed head and a thin cephalion. At the posterior end two short styli are present each carrying three setae/bristles, of which one is much longer than the other two. Four pairs of spine groups are present, originating ventrally or ventrolaterally. The three anterior groups consist of spines with two denticles, while the spines of the posteriormost spine group have only one denticle with a small bifurcation at their ends. From anterior to posterior each group consists of 3,3,2 and 1 spine/s. The first group is situated in the neck region and has the longest spines. Spines of group 2 and 3 are of approximately equal length. The single spine of the last group is much shorter than those of the anterior groups. Locomotory ciliature consists of five ventral ciliary tufts and three pairs of semi-circular ciliary tufts on the head. Pharynx short but with strong posterior swelling.

Previously reported from Germany (Schwank 1990), United States (Brunson 1950; Schwank 1990) and Canada (Schwank 1990).
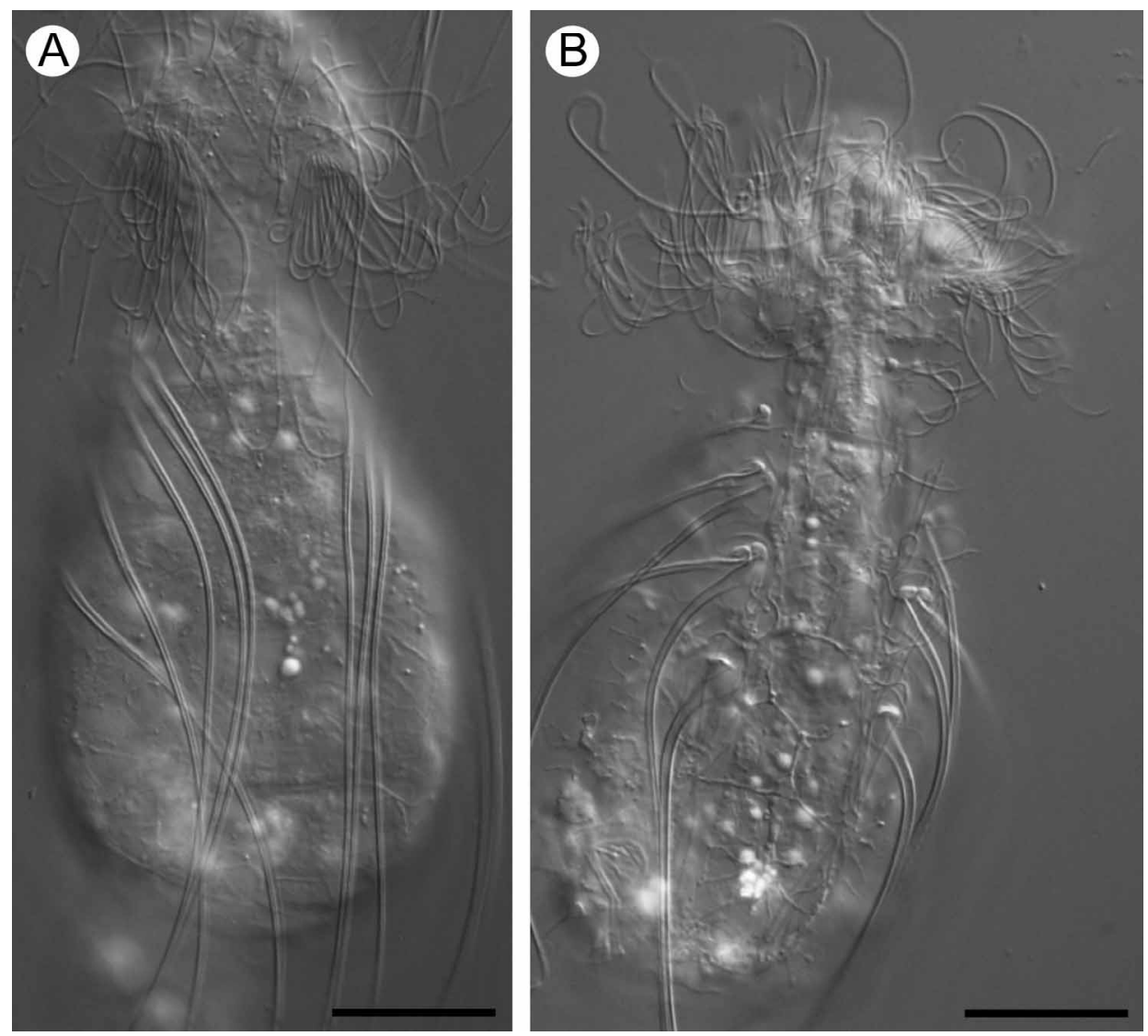

FIGURE 17. Haltidytes crassus. A) Dorsal view. B) Ventral view showing insertion of spines. Scale bars: A and B, $20 \mu \mathrm{m}$. 


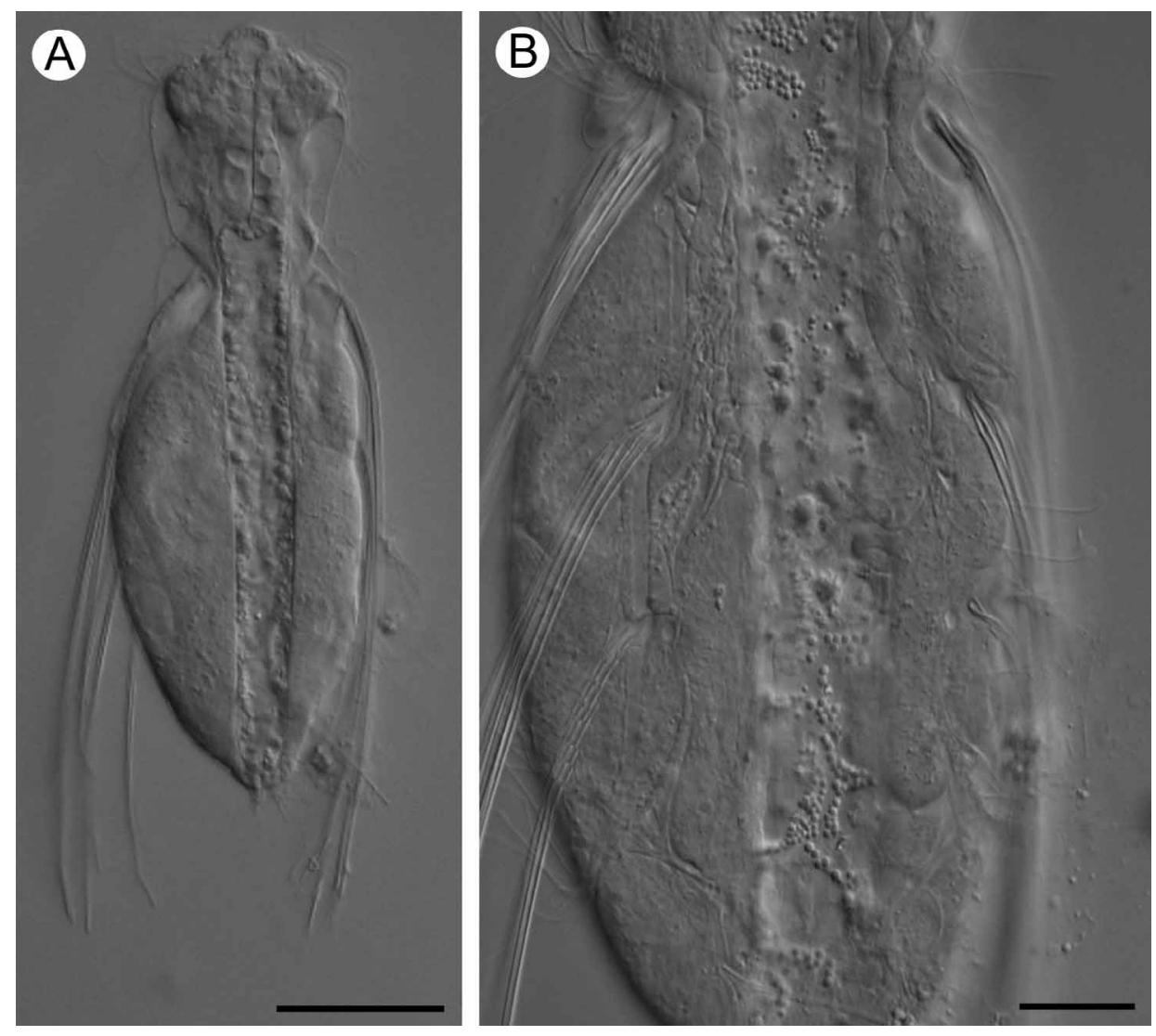

FIGURE 18. Stylochaeta scirtetica. A) Habitus. B) Ventral view showing insertion of four of the five pairs of spine groups. Scale bars: A, $40 \mu \mathrm{m} ; \mathrm{B}, 15 \mu \mathrm{m}$.

\section{Discussion}

This study presents two new species of Heterolepidoderma, H. joermungandri n. sp. and H. trapezoidum $\mathbf{n}$. sp. Moreover, the first Swedish records of Aspidiophorus oculifer, A. ophiodermus, Heterolepidoderma macrops, $H$. ocellatum, Lepidochaetus zelinkai, Lepidodermella minor minor, Polymerurus nodicaudus, Haltidytes crassus and Stylochaeta scirtetica are presented, increasing the number of known freshwater gastrotrichs in Sweden to 31.

From a biogeographical point of view the known number of freshwater Gastrotricha from Sweden is still low compared to other well investigated countries. Many of the Swedish species share characters in common with their Polish conspecifics. The Polish gastrotrich fauna is one of the best known in the world with 98 recorded freshwater gastrotrichs (see e.g. Kisielewski 1981; 1998). Sweden hosts a wide variety of habitats common to temperate and boreal areas and is known for its lakes and wetlands, and compared to Poland, the country can be hypothesized to harbor well above 100 freshwater species.

Both apparently cosmopolitan species and species with a limited geographic distribution were found during this investigation. L. squamata and L. zelinkai are considered more or less cosmopolitan species, and they were found at 12 and 8 sites respectively, out of a total of 29 investigated sites. L. zelinkai is a good candidate for barcoding and phylogeographic studies within Chaetonotidae since it is common and can be identified with a good dissecting microscope. Species found in Sweden with a more restricted distribution are members of Aspidiophorus, Heterolepidoderma, Lepidodermella and Stylochaeta.

Future faunistic and taxonomic studies of Swedish Gastrotricha should focus on the freshwater interstitial, larger lakes and lotic waters. 


\section{Acknowledgements}

Thanks go to Dr. M. Antonio Todaro and Dr. Sven Boström for constructive comments on an early draft of the manuscript. I am grateful to Dr. Diego Fontaneto for collecting some of the samples and to Dr. William Hummon and Mr. James Kirk for helping out during the course of this study. I would also like to thank Dr. Alexander Kieneke and an anonymous reviewer for improving the manuscript. This study was financially supported by a grant from the Swedish Taxonomy Initiative to Dr. Ulf Jondelius and by several grants, supplied by Abisko Scientific Research Station, Riksmusei Vänner and Helge Ax:son Johnson Foundation (to TK).

\section{References}

Anderson, M.T. \& Robbins, C.E. (1980) A new species of gastrotrich from Illinois. Transactions of the American Microscopical Society, 99, 225-227.

Artois, T., Fontaneto, D., Hummon, W.D., McInnes, S.J., Todaro, M.A., Sørensen, M.V. \& Zullini, A. (2011) Ubiquity of microscopic animals? Evidence from the morphological approach in species identification. In: Fontaneto, D. (Ed.), Biogeography of Microscopic Organisms: Is Everything Small Everywhere? Cambridge University Press, pp. 245-249.

Balsamo, M. (1978) Prime ricerche sui Gastrotrichi dulciacquicoli italiani. Atti della Societa Toscana di Scienze Naturali Memorie, Serie B, 84, 87-150 (1977).

Balsamo, M. (1982) Three new gastrotrichs from a Tuscan-Emilian Apennine lake. Bollettino di Zoologia, 49, $287-295$ (1983).

Balsamo, M. (1983) Gastrotrichi. In: Consiglio Nazionale delle Ricerche. Guide per il riconoscimento delle specie animali delle acque interne italiane, 20, 1-92.

Balsamo, M. (1990) Gastrotrichs from lakes Bolsena, Chiusi and Montepulciano (central Italy), with the description of four new species. Bollettino di Zoologia, 57, 165-178.

Balsamo, M. \& Fregni, E. (1995) Gastrotrichs from interstitial fresh water, with a description of four new species. Hydrobiologia, 302, 163-175.

Balsamo, M., d'Hondt, J.L., Kisielewski, J., Pierboni, L. (2008) Global diversity of gastrotrichs (Gastrotricha) in fresh waters. Hydrobiologia, 595, 85-91.

Balsamo, M., d'Hondt, J.L., Pierboni, L. \& Grilli, P. (2009) Taxonomic and nomenclatural notes on freshwater Chaetonotida (Gastrotricha). Zootaxa, 2158, 1-19.

Balsamo, M. \& Todaro, M.A. (1995) Gastrotrichi del Trentino: le Viotte del Monte Bondone. Studi Trentini di Scienze Naturali-Acta Biologica, 70, 9-22.

Balsamo, M. \& Todaro M.A. (2002) Gastrotricha. In: Rundle, S.D., Robertson A.L \& Schmid-Araya, J.M. (Eds.), Freshwater Meiofauna: Biology and Ecology. Backhuys Publishers, Leiden, pp. 45-61.

Balsamo, M. \& Tongiorgi, P. (1995) Gastrotricha. In: Minelli, A., Ruffo, S \& La Posta, S (Eds.), Checklist delle Specie della Fauna d'Italia. Calderini, Bologna, 7, 1-11.

Blake, C.H. (1933) Nomenclatorial notes on Gastrotricha. Science, 77, 606.

Brehm, V. (1917) Ergebnisse einiger im Franzensbader Moor unternommener Exkursionen. Archiv für Hydrobiologie, 11, 306323.

Brunson, R.B. (1950) An introduction to the taxonomy of the Gastrotricha with a study of eighteen species from Michigan. Transactions of the American Microscopical Society, 69, 325-352.

Bryce, D. (1924) The Rotifera and Gastrotricha of Devils and Stump Lakes, North Dakota, USA. Journal of the Quekett Microscopical Club, 15, 81-108.

Cordero, E.H. (1918) Notes sur les Gastrotriches. Physis, 4, 241-244.

Daday, E. von. (1905) Untersuchungen über die Süsswasser Mikrofauna Paraguays. Zoologica, 44, 1-374.

Daday, E. von. (1910). Die Süsswasserfauna Deutsch-Ost Afrikas. Zoologica, 23, 56-59.

Davison, D.B. (1938). A new species of gastrotrichan - Chaetonotus robustus, new species. American Museum Novitates, 972 , $1-6$.

Dujardin, F. (1841) Histoire Naturelle des Zoophytes, Infusoires. Librairie Encyclopedique de Roret, Paris, 684 pp. and atlas p. 12, pl. 18.

Ehrenberg, C.G. (1830) Organisation, Systematik, und geographisches Verhältnis der Infusionstierchen. F. Dümmler, Berlin, $108 \mathrm{pp}$.

Ehrenberg, C.G. (1832) Über die Entwickelung und Lebensdauer der Infusionsthiere. Abhandlung der Akademie der Wissenschaftes zu Berlin, 1-154 Taf. III, Fig. 6. (1831)

Evans, W.A. (1993) First report of Lepidodermella squamata (Gastrotricha: Chaetonotida) from Lake Erie. The Ohio Journal of Science, 93, 111-112.

Fregni, E., Balsamo, M. \& Tongiorgi, P. (1998) Interstitial gastrotrichs from lotic Italian fresh waters. Hydrobiologia, 368, 175187.

Gosse, P.H. (1864) The natural history of the hairy-backed animalcules (Chaetonotidae). The Intellectual Observer, 5, 387-406.

Greuter, A. (1917) Beiträge zur Systematik der Gastrotrichen in der Schweiz. Revue Suisse de Zoologie, 25, 35-76.

Grilli, P., Kristensen, R.M. \& Balsamo, M. (2009) Heterolepidoderma caudosquamatum (Gastrotricha. Chaetonotida), a new species from brackish waters of Denmark. Zootaxa, 2173, 49-54. 
Grilli, P., Kristensen, R.M \& Balsamo, M. (2010) Contribution to the knowledge of the freshwater Gastrotricha from Denmark. Steenstrupia, 32, 79-92.

Grosso, L.E. (1973) Notas sobre Gastrotricos Argentinos II. Neotropica, 19, 87-89.

Grosso, L.E. (1975) Especies Argentinas del genero Polymerurus Remane 1927. Neotropica, 21, 46-50.

Grosso, L.E. (1976) Chaetonotus berissensis n. sp. (Gastrotricha) relacionada a los organos sumergidos de plantas flotantes. Neotropica, 22, 121-124.

Grosso, L.E. \& Drahg, F. (1983) Gastrotricos dulceacuicolas de la provincia de Tucuman I. Chaetonotus soberanus sp. nov. y Aspidiophorus lilloensis sp. nov. Neotropica, 29, 189-193.

Grosso, L.E. \& Drahg, F. (1984) Gastrotricos dulceacuicolas de la provincia de Tucuman II. Chaetonotus majestuosus n. sp. Acta Zoologica Lilloana, 37, 227-230.

Grosso, L.E. \& Drahg, F. (1991) Gastrotricos dulceacuicolas de la provincia de Tucuman IV. Acta Zoologica Lilloana, 40, 4751.

Grünspan, T. (1908) Beiträge zur Systematik der Gastrotrichen. Zoologische Jahrbücher Systematik, 26, 214-256.

Hlava, S. (1904) Über die systematische Stellung von Polyarthra fusiformis Spencer. Zoologischer Anzeiger, 28, 331-336.

Hochberg, R. (2005) First record of Polymerurus (Gastrotricha, Chaetonotida) from Australia with the description of a new species from Queensland and of cuticular ultrastructure in P. nodicaudus. Invertebrate Biology, 124, 119-130.

Hofsten, N. von. (1923) Rotatorien der Nordschwedischen Hochgebirge. Naturwissenschaftliche Untersuchungen des Sarekgebirges in Schwedish-Lappland geleitet von A. Hamberg, Zoologie, 4, 829-894.

d'Hondt, J.L. (1971) Gastrotricha. In: Barnes, H. (Ed.), Oceanography and marine biology: an annual review, 9. George Allen and Unwin Ltd., pp. 141-192.

Hummon, W.D. (1982) Gastrotricha, In: Parker, S.P. (Ed.), Synopsis and Classification of Living Organisms, 1. McGraw-Hill, New York, pp. 857-863.

Hummon, W.D., Balsamo, M. \& Todaro, M.A. (1992) Italian marine Gastrotricha: I. Six new and one redescribed species of Chaetonotida. Bollettino di Zoologia, 59, 499-516.

Kånneby, T., Todaro, M.A. \& Jondelius, U. (2009) One new species and records of Ichthydium Ehrenberg, 1830 (Gastrotricha: Chaetonotida) from Sweden with a key to the genus. Zootaxa, 2278, 26-46.

Kisielewski, J. (1979) New and insufficiently known freshwater Gastrotricha from Poland. Annales Zoologici, 34, 415-435.

Kisielewski, J. (1981) Gastrotricha from raised and transitional peat bogs in Poland. Monografie Fauny Polski, 11. Polska Akademia Nauk, Warszawa, 143 pp.

Kisielewski, J. (1986) Taxonomic notes on freshwater gastrotrichs of the genus Aspidiophorus Voigt (Gastrotricha, Chaetonotoidea) with description of four new species. Fragmenta Faunistica, 30, 139-156.

Kisielewski, J. (1988) New records of marine Gastrotricha from the French coasts of Manche and Atlantic. II Chaetonotida, with descriptions of four new species. Cahiers de Biologie Marine, 29, 187-213.

Kisielewski, J. (1991) Inland-water Gastrotricha from Brazil. Annales Zoologici Warszawa, 43, 1-168.

Kisielewski, J. (1998) Brzuchorzeski (Gastrotricha). Fauna Slodkowodna Polski, Zeszyt 31. Windawnictwo Uniwersytetu Lodzkiego, Lódz, 157 pp.

Kisielewski, J. (1999) A preliminary study of the inland-water Gastrotricha of Israel. Israel Journal of Zoology, 45, $135-157$.

Leasi, F \& Todaro, M.A. (2008) The muscular system of Musellifer delamarei (Renaud-Mornant, 1968) and other chaetonotidans with implications for the phylogeny and systematization of the Paucitubulatina (Gastrotricha). Biological Journal of the Linnean Society, 94, 379-398.

Lee, J.M. \& Chang, C.Y. (2000) Freshwater Chaetonotid Gastrotrichs in Korea. The Korean Journal of Systematic Zoology, 16, $87-104$

Marcolongo, I. (1910) Primo contributo allo studio dei Gastrotrichi del lago-stagno craterico di Astroni. Monitore Zoologico Italiano, 21, 315-318.

Marcolongo, I. (1914) I Gastrotrichi del lago-stagno craterico di Astroni. Atti della Reale Accademia Scienze Fisiche e Matematiche di Napoli, Series 2A, 15, 1-25.

Martin, L.V. (1981) Gastrotrichs found in Surrey. Microscopy, 34, 286-301.

Martin, L.V. (1990) Further observations on Gastrotrichs in Surrey and a provisional British list. Microscopy, 36, 415-425.

Metschnikoff, E. (1865) Über einige wenig bekannte niedere Thierformen. Zeitschrift für Wissenschaftliche Zoologie, 15, 450463.

Mock, H. (1979) Chaetonotoidea (Gastrotricha) der Nordseeinsel Sylt. Mikrofauna des Meeresbodens, 78, 405-507.

Mola, P. (1932) Gastrotricha delle acque dolci italiane. Internationale Revue der Gesamten Hydrobiologie und Hydrographie, 26, 397-423.

Naidu, K.V. \& Rao, G.C (2004) The Fauna of India and the adjacent countries-Gastrotricha. Zoological Survey of India, Kolkata, $169 \mathrm{pp}$.

Preobrajenskaja, E.N. (1926) Zur Verbreitung der Gastrotrichen in den Gewässern der Umgebung von Kossino. Arbeiten der Biologischen Station zu Kossino (Moskau), 4, 1-14.

Rao, G.C. \& Clausen, C. (1970) Planodasys marginalis gen. et. sp. nov. and Planodasyidae fam. nov. (Gastrotricha Macrodasyoidea). Sarsia, 42, 73-82.

Remane, A. (1925) Organisation und systematische Stellung der aberranten Gastrotrichen. Verhandlungen der deutschen zoologischen Gesellschaft, 30, 121-128.

Remane, A. (1927) Beiträge zur Systematik der Süsswassergastrotrichen. Zoologische Jahrbücher Abteilung für Systematik Oekologie und Geographie der Tiere, 53, 269-320.

Remane, A. (1935-36) Gastrotricha und Kinorhyncha. In: Bronn, H.G. (Ed.), Klassen und Ordnungen des Tierreichs, Band 4, 
Abteilung 2, Buch 1, Teil 2, Lieferungen 1-2. Akademie Verlagsgesellschaft, Leipzig, pp. 1-385.

Renaud-Mornant, J. (1967) Heterolepidoderma foliatum n. sp. (Gastrotricha, Chaetonotoidea) des faciés Saumâtres du bassin d'Arcachon. Bulletin de la Sociét Zoologique de France, 92, 161-167.

Roszczak, R. (1936) Brzuchorzeski (Gastrotricha) zbiornikow wodnych okolic Poznania, Spraw. Towarzystwo Przyjacił Nauk, 9, 109-111 (1935).

Roszczak, R. (1969) Brzuchorzęski (Gastrotricha) srodkowej Wielkopolski. Poznańskie towarzystwo przyjacit nauk. Wydziat matematyczno-przyrodniczy. Prace Komisji biologicznej, 32, 1-92 (1968).

Rudescu, L. (1967) Gastrotricha. In: Fauna Republicii Socialiste Romania, Trochelminthes, 2(3). Academia Republicii Socialiste Romania, Bucharest, 292 pp.

Saito, I. (1937) Neue und bekannte Gastrotrichen der Umgebung von Hirosima (Japan). Journal of Science of the Hirosima University Series B, 5, 245-265.

Schrom, H. (1966) Gastrotrichen aus Feinsanden der Umgebung von Venedig. Bollettino del Museo Civico di Storia Naturale di Venezia, 17, 31-45.

Schrom, H. (1972) Nordadriatische Gastrotrichen. Helgoländer wissenschaftliche Meeresuntersuchungen, 23, $286-351$.

Schwank, P. (1990) Gastrotricha. In: Schwoerbel, J. \& Zwick, P. (Eds.), Süsswasserfauna von Mitteleuropa, Band 3. Gastrotricha und Nemertini. Gustav Fischer Verlag, Stuttgart, Jena, New York, pp. 1-252.

Stokes, A.C. (1887) Observations on Chaetonotus. The Microscope, 7, 33-43.

Sudzuki, M. (1971) Die das Kapillarwasser des Lückensystems bewohnenden Gastrotrichen Japans II. Bulletin of the Biogeographical Society of Japan, 27, 37-41.

Sudzuki, M. (1975) List of Rotifera and Gastrotricha from garden ponds of Tokyo 1974-75 and some notes on Rhinoglena, Fadeewella, Neogossea, etc. Proceedings of the Japanese Society of Systematic Zoology, 11, 5-12.

Togouet Zébazé, S.H., Njine, T, Kemka, N., Nola, M., Menbohan, S.F., Koste, W., Boutin, C. \& Hochberg, R. (2007).

Spatio-temporal changes in the abundance of the populations of the gastrotrich community in a shallow lake of tropical Africa. Limnologica, 37, 311-322.

Tretjakova, E.I. (1989) K poznaniju fauny presnovodnych gastrotrich Evropejskoj casti SSSR. Gosudarstvennyj Komitet SSSR po Narodnoти Obrazovaniju, redkollegija zurnala "Biologieeskie Nauki, udk 595.132 (maszynopis, 21 pp).

Tretjakova, E.I. (1991) Lepidodermella spinifera, a new species of Gastrotricha with intermediate generic features. Byulletin Moskovogo Obshchestva Ispytatelej Prirody, Otdel Biologiceskij, 96, 79-85.

Valkanov, A. (1937) Über die Gastrotrichen Bulgariens. Zoologische Jahrbücher Abteilung für Systematik Oekologie und Geographie der Tiere, 70, 171-176.

Varga, L. (1963) Aspidiophorus silvaticus n. sp., eine neue bodenbewohnende Gastrotrichen-Art. Acta Zoologica Academiae Scientiarum Hungaricae, 9, 209-217.

Voigt, M. (1901a) Diagnosen bisher unbeschriebener Organismen aus Plöner Gewässern. Zoologischer Anzeiger, 25 , 35-39.

Voigt, M. (1901b) Mittheilungen aus der Biologische Station zu Plön, Holstein. Über einige bisher unbekannte Süsswasserorganismen. Zoologischer Anzeiger, 24, 191-195.

Voigt, M. (1903) Eine neue Gastrotrichenspecies (Chaetonotus arquatus) aus dem Schlossparkteiche zu Plön. Plöner Forschungsberichte, 10, 90-93.

Voigt, M. (1904) Rotatorien und Gastrotrichen der Umgebung von Plönsbiotopen. Forschungsberichte aus der Biologischen Station zu Plön, 11, 1-178.

Wilke, U. (1954) Mediterrane Gastrotrichen. Zoologische Jahrbücher Abteilung für Systematik Oekologie und Geographie der Tiere (Jena), 82, 497-550.

Zelinka, C. (1889) Die Gastrotrichen. Eine monographische Darstellung ihrer Anatomie, Biologie und Systematik. Zeitschrift für Wissenschaftliche Zoologie, 49, 209-384. 